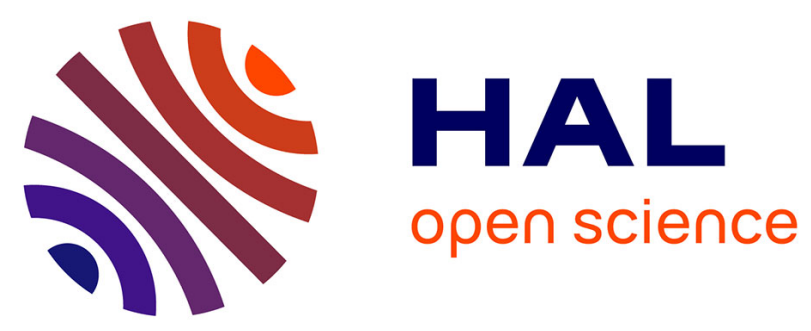

\title{
Drivers and barriers to pre-adoption of strategic scanning information systems in the context of sustainable supply chain
}

Nicolas Lesca, Marie-Laurence Caron-Fasan, Edison Loza Aguirre, Marie-Christine Chalus-Sauvannet

\section{To cite this version:}

Nicolas Lesca, Marie-Laurence Caron-Fasan, Edison Loza Aguirre, Marie-Christine Chalus-Sauvannet. Drivers and barriers to pre-adoption of strategic scanning information systems in the context of sustainable supply chain. Systèmes d'Information et Management, 2015, 20 (3), pp.9-46. 10.9876/sim.v20i3.580 . halshs-01337216

\section{HAL Id: halshs-01337216 \\ https://shs.hal.science/halshs-01337216}

Submitted on 24 Jun 2016

HAL is a multi-disciplinary open access archive for the deposit and dissemination of scientific research documents, whether they are published or not. The documents may come from teaching and research institutions in France or abroad, or from public or private research centers.
L'archive ouverte pluridisciplinaire HAL, est destinée au dépôt et à la diffusion de documents scientifiques de niveau recherche, publiés ou non, émanant des établissements d'enseignement et de recherche français ou étrangers, des laboratoires publics ou privés. 


\title{
Drivers and barriers to pre-adoption of strategic scanning information systems in the context of sustainable supply chain
}

\author{
Nicolas LESCA* \\ Marie-Laurence CARON-FASAN* \\ Edison LOZA AGUIRRE* \\ Marie-Christine CHALUS-SAUVANNET** \\ * CERAG-CNRS UMR 5820, Université Grenoble Alpes, France \\ ** IAE de Lyon, France
}

\begin{abstract}
This research is reporting on the pre-adoption of Strategic Scanning (S.Scan) information systems (IS). More specifically, it relates to the pre-adoption phase, that is, the emergence of the idea of such a system and the evaluation of its need for the organization, upstream of any technological consideration. The research question is the following: what are the drivers and barriers that influence the pre-adoption of a S.Scan IS? The objective of this research is to extend knowledge on a subject that has received little attention from the scholars. Research's originality relies on the use of isomorphic processes from neo-institutional framework to study pre-adoption in the field of S.Scan. On the basis of a multi-method research combining qualitative and quantitative exploratory studies in the specific field of sustainable supply chains (SSC), our results highlight 31 drivers and barriers to pre-adoption of S.Scan IS, ten of which have not been identified before, and five types of pressures. They therefore suggest that pre-adoption of S.Scan IS can be subject to both functional and institutional pressures. It can be driven either by competitiveness or conformism pressures, and hindered by performance objectives or lack of coercive pressures. Finally, these results put a question mark about the understanding of the strategic dimension of S.Scan IS by organisations, and the government's role and its responsibility for promoting SSC initiatives and for the adoption of S.Scan IS on this issue.
\end{abstract}

\section{Keywords}

strategic scanning, sustainable supply chain, adoption, pre-adoption, institutional theory, drivers, barriers. 


\title{
Motivations et freins à la pré-adoption d'un système d'information de veille stratégique dans le contexte de la logistique durable
}

\author{
Nicolas LESCA* \\ Marie-Laurence CARON-FASAN* \\ Edison LOZA AGUIRRE* \\ Marie-Christine CHALUS-SAUVANNET*** \\ * CERAG-CNRS UMR 5820, Université Grenoble Alpes, France \\ ** IAE de Lyon, France
}

\begin{abstract}
Résumé
Cette recherche porte sur l'adoption d'un système d'information (SI) de veille stratégique (VS). Plus précisément, elle porte sur la phase de pré-adoption, c'est-à-dire l'émergence de l'idée d'un tel système et l'évaluation de son besoin pour l'organisation, en amont de considérations technologiques. La question de recherche est la suivante : quels sont les motivations et les freins qui influencent la pré-adoption d'un SI de VS ? L'objectif est ainsi de contribuer à enrichir les connaissances sur un sujet qui a été peu abordé dans la littérature. L'originalité de l'article est de mobiliser les travaux sur les processus porteurs de changements institutionnels isomorphiques du cadre néo-institutionnel pour étudier la préadoption dans le champ de la VS. Sur la base d'une démarche multi-méthodes, qui combine étude exploratoire qualitative et quantitative, dans le contexte spécifique de la logistique durable (LD), nos résultats révèlent 31 motivations et freins à la pré-adoption d'un SI de VS, dont dix nouveaux, et cinq types de pressions. Ils suggèrent ainsi que la pré-adoption d'un SI de VS peut être soumise à la fois à des pressions fonctionnelles et institutionnelles. Elle peut être motivée par des objectifs de compétitivité et de mimétisme, et freinée par des objectifs de performance et par l'absence de pressions coercitives. Ces résultats questionnent finalement la compréhension par les entreprises du caractère stratégique du SI de VS, ainsi que le rôle et la responsabilité de l'Etat dans le développement de la LD et l'adoption de SI de VS dans le contexte de la LD.
\end{abstract}

\section{Mots clés}

veille stratégique, logistique durable, adoption, pré-adoption, théorie néo-institutionnelle, motivations, freins 


\section{Introduction}

The sustainability and competitiveness of an organization (Jennings \& Lumpkin, 1992; Wei \& Lee, 2004) partially depend on its capacity to understand and anticipate changes in its external environment (Xu, Kaye et al., 2003), to reduce the uncertainty related to decisionmaking (Walkers, Jiang et al., 2003), to adjust its strategy and objectives (Choo, 2001), and to adapt its tactics. This implies, in particular, being able to collect and filter out relevant information (Mosley Roche, 1996) that is often drowned in the flow of over-abundant information, to share and disseminate it to the concerned individuals, to analyse the information, and to use it to create sense for the organization (Rouibah \& Ould-Ali, 2002). Strategic scanning (S.Scan hereafter) can help an organization develop this capacity to understand and anticipate developments in its external environment.

S.Scan has been studied from different angles. Many studies have focused on S.Scan practices and their partial instrumentation in the form of methods (i.e. Gilad \& Gilad, 1988; Choo, 1999) or technologies (i.e. Zhang, Dang et al., 2009; Chung 2014). More recent research shows how scanning practices contribute to generating representations of the external environment (Belmondo, 2008) and to strengthening the absorptive capacity of organizations (Amabile, Meissonier et al., 2012). Rarer are the works that study S.Scan as an information system (IS), that is to say, a whole structure of human, technological, informational and procedural resources which collect, transform, store, and disseminate information in an organization (Reix, Fallery et al., 2011), and is designed and implemented to manage a process and assist individuals in execution functions, management and decision-making (Lesca, Lesca et al., 2010). Some research has shown, however, that S.Scan is a complex system (Lesca \& Caron-Fasan, 2005) which success, effectiveness and sustainability are subject to many factors of failure and abandonment, as much in its design phase, as during implementation and production (Lesca \& Caron-Fasan, 2008; Caron-Fasan \& Lesca, 2012). In contrast, the pre-adoption of an S.Scan IS (upstream for its design and implementation) has not yet been studied.

In the literature, ISs for S.Scan are neither clearly defined, nor truly homogeneous. For all the authors, S.Scan is an informational process whose purpose is to help a company know and understand the developments in its external environment and to support decisions (Choo, 1999). In the French context, the scanning process was, in particular, the subject of the AFNOR standard X50-053. According to the authors and contexts, the S.Scan process can take very different forms (i.e. Wei \& Lee, 2004; Mayer, Steinecke et al., 2013). It can be individual, informal and non-structured, or on the contrary, organized and centralized, for example in the form of a cell, a service, or an observatory (Baumard, 1997; Belmondo, 2003). The place of IT to support this process can also be extremely varied. The process of S.Scan can be fully computerized in the form of a dedicated platform (this is the case with the DIGIMIND Intelligence and AMI Smart Horizon IT solutions). In this case S.Scan IS is part of decision support systems (Reix, Fallery et al., 2011). But S.Scan ISs can also be based on a combination of tools, sometimes numerous, loosely related to S.Scan, weakly integrated and urbanized (for example search engines like Google or curation tools such as Scoop it! to collect information, email messages for their dissemination, Excel spreadsheets for their organization, or an intranet for their storage, sharing and archiving).

Pre-adoption of an IS is a phase of awareness and recognition of a need, of information gathering, and of evaluation of an IS ability to meet this need (Hameed, Counsell et al., 2012). During the S.Scan IS pre-adoption phase stakeholders are concerned about the need for an S.Scan IS for their organization. Some organizations have no scanning activity and wonder about the possibility of creating an S.Scan IS ex-nihilo. Others already possess scanning 
activity and wonder about the need to strengthen their activity by a new form of scanning. For example, a company may have a scanning IS targeting their competitors and reflect upon the need to complement it with a scanning IS oriented toward its reputation, or technology and patents (which implies new resources, a new process, new tools, new data collection, etc.). In this way companies assess, on the one hand, the usefulness and the opportunity to invest resources in the implementation of such an IS, and on the other hand, its feasibility and adaptability to the specific context of their organization. This evaluation sometimes leads to the decision to study those S.Scan ISs present on the market in order to make a choice. But it can also lead to the decision that S.Scan is not a priority for the organization, and therefore to not adopt such an IS, or to postpone this decision. For example, faced with sustainable development challenges in the transport sector - notably in terms of $\mathrm{CO} 2$ emissions limitations, the evolution of the regulatory framework, or innovations - a logistics service provider (LSP) may pose questions concerning the value of investing resources in a specific S.Scan IS dedicated to sustainable supply chain, and about its S.Scan IS needs to develop its capacity to anticipate future changes rather than being subjected to them. On the other hand, another LSP may choose to become informed, react and adapt only when these changes are a reality, or other LSPs innovate, believing that they do not need a specific S.Scan IS to develop their own sustainable supply chain.

As illustrated by these two examples, our study falls under the particular context of sustainable supply chain (noted SSC hereafter). Logistics is sustainable when its performance is measured as much by economic dimensions as by social and environmental dimensions (Pagell \& Wu, 2009). SSC is a subject that organizations are slowly addressing, but its implementation faces many barriers (Giunipero, Hooker et al., 2012). One of the main barriers is lack of information which leads organizations to not engage in SSC (Walker, di Sisto et al., 2008). S.Scan may constitute a solution for getting around this informational barrier because it can help anticipate future developments and opportunities in the SSC field, identify potential constraints in order to transform them into opportunities, and finally to move from a reactive posture vis a vis external pressures to a more proactive and anticipatory approach (Fabbes-Costes, Roussat et al., 2011). The decision to adopt an SSC is accompanied by various pressures which may be at the root of major organizational changes (Jennings \& Zandbergen, 1995; Connor \& Dovers, 2004; Bansal, 2005). The SSC context is therefore particularly relevant for studying the pressures that explain the drivers and barriers to preadoption of a (new) SSC oriented S.Scan IS.

If IS pre-adoption has attracted the attention of authors (Burton Swanson \& Ramiller, 2004; Hameed, Counsell et al., 2012), pre-adoption of a new S.Scan IS has not yet been the subject of published studies. The theory of institutional isomorphism (DiMaggio \& Powell, 1983) allows explaining IS pre-adoption, and in particular, may also allow deepening the understanding of internal and external institutional pressures which contribute to driving or hindering the adoption of a new S.Scan IS. However, this theory has never been mobilized in this context. Similarly, although there is an abundant literature, including on the one hand, the missions and objectives of S.Scan which demonstrate the value of S.Scan, and on the other hand, factors of failure and abandonment of S.Scan projects, the drivers and barriers to S.Scan IS pre-adoption have not been the subject of published studies. By combining the known factors of failure and abandonment likely to motivate or to curb S.Scan IS pre-adoption, and the theory of institutional isomorphism, we seek to identify the barriers and the drivers that influence the pre-adoption of an S.Scan IS.

The objective of this study is to answer the following question: What are the drivers and barriers which influence the pre-adoption of an S.Scan IS? To do this, we mobilize the symbolic adoption model (Klonglan \& Coward, 1970) to clarify the concept of pre-adoption 
of an S.Scan IS, and we adopt a multi-method approach. A first, exploratory qualitative study based on 42 semi-structured interviews was designed to identify the barriers and drivers specific to the pre-adoption of an S.Scan IS. To do this, we start from previously identified knowledge on factors of failure and success mentioned by the literature on S.Scan to identify those elements that could act as drivers for or barriers to pre-adoption. This first study allowed us to identify 31 drivers and barriers to S.Scan IS pre-adoption, including 10 new items that were not previously noted in the S.Scan literature. A second study, this one of an exploratory quantitative nature, was undertaken on the basis of a questionnaire constructed from the results of the qualitative study, and aimed at identifying the internal and external pressures that motivate or inhibit the pre-adoption of an S.Scan IS. To interpret these results, we mobilize the neo-institutional perspective, and more specifically the theory of institutional isomorphism to identify the institutional (DiMaggio \& Powell, 1983) and functional (Oliver, 1992) pressures likely to motivate or to curb pre-adoption of S.Scan ISs. The findings of this second study suggest that S.Scan IS pre-adoption can be subject to five types of functional and institutional pressure. It may be motivated by objectives of competitiveness and conformism, and inhibited by performance objectives and by the absence of coercive pressures.

The first part presents the mobilised theoretical framework. The second part explains the context of the research and the adopted methodology. The results are presented in the third part and discussed in the last part. We hope that this study will deliver useful knowledge to help better understand the drivers and the barriers to the pre-adoption of an S.Scan IS. The results will also help practitioners to intelligently assess the reasons for which they decide whether to or not to adopt such an IS.

\section{Theoretical framework of the research}

\subsection{Pre-adoption of an information system for strategic scanning}

The adoption of an IS refers to the process by which an IS is introduced into a social system in order to support its operations, management and decision-making (Cooper \& Zmud, 1990; Thong, 1999; Baskerville \& Pries-Heje, 2001). Adoption covers a set of cognitive states, ranging from awareness of a technology's existence through to its implementation (Rogers, 1983). Research on IS adoption distinguishes between three phases (Hameed, Counsell et al., 2012) (see Appendix A):

- Pre-adoption is a phase of realization and recognition of a need, information gathering, and for evaluation of ISs able to respond to the need.

- Adoption is a phase of decision-making and implementation of the IS.

- Post-adoption is a phase of routinisation and assimilation of the IS.

The model of symbolic adoption is one of the few theoretical frameworks that allows explanation of the pre-adoption of an IS (Verra, Karoui et al., 2012). This model shows that in order to decide whether to adopt an IS, it is necessary that the individuals be aware of its existence, that they learn about it through information gathering, that they assess its relevance in relation to their needs, and that they intellectually (symbolically) accept the idea of adoption (Klonglan \& Coward, 1970; Sapp \& Korsching, 2004). Symbolic adoption is therefore presented as a necessary prerequisite to "hardware" adoption (see Appendix A). 
The symbolic adoption model allows us to better clarify the concept of pre-adoption in the context of S.Scan. It corresponds to the phase during which a leadership team reflects on the ability of the organization to be informed of developments in its internal and external environments, as well as on the need to strengthen this ability to reduce the uncertainty of decision-making, and steer the organization in the future. The leadership team analyses the relevance of the idea of S.Scan and of a new S.Scan IS. On the one hand, they evaluate its usefulness in terms of the organization's needs, as well as the opportunity to invest in the implementation of an S.Scan IS to complement or modify current practices. On the other hand, they evaluate its feasibility in the specific context of the organization. This evaluation sometimes leads to the decision to more closely study the S.Scan IS market to become acquainted with the offers. But the leadership team may also not recognize the need for an S.Scan IS, or even estimate that this need is not a priority, or that a new S.Scan IS is not an appropriate solution to meet the organization's needs. At this stage of reflection, the question is still neither in terms of specifications for a possible future S.Scan IS, nor in terms of choice of IS technology. This question arises in the adoption phase if the need for a new S.Scan IS and its priority are recognized by the management team. Thus defined (in light of the symbolic adoption model) pre-adoption is the result of an awareness and recognition of the need for a new S.Scan IS, while "hardware" adoption focuses more on the evaluation of and commitment to a new technology or a new, precise, and clearly identified S.Scan IS.

Although pre-adoption of a new S.Scan IS has not yet been the subject of published studies, IS pre-adoption, on the other hand, has retained the attention of authors. Some of these studies, which employ the neo-institutional theoretical framework (Williams, Lueg et al., 2009; Hofer, Hofer et al., 2011), and more specifically the theory of institutional isomorphism (Di Maggio \& Powell, 1983), show that the decision to adopt or not to adopt an IS does not merely respond to rational needs and efficiency, but that it can also be explained by institutional pressures. Organizations that produce similar services or products, or that share suppliers, resources, or customers, are subject to similar internal and external institutional pressures. Because of this, they tend toward a form of homogenization or structural standardization to enhance their legitimacy. They thus tend to adopt practices considered legitimate by their counterparts (Pfeffer \& Salancik, 1978; Meyer \& Rowan, 1991; Jepperson, 1991; Schuman, 1995) and to invest in IS, for among other reasons, to respond to institutional pressures and maintain their legitimacy (Lai, Wong et al., 2006; Abdennadher \& Cheffi, 2011). In the context of our study, the theory of institutional isomorphism allows exploration and identification of internal and external institutional pressures which contribute to motivating or hindering the adoption of a new S.Scan IS.

\subsection{The theory of institutional isomorphism: a theoretical framework to study institutional pressures that influence pre-adoption of an S.Scan IS}

In the theory of institutional isomorphism, the homogenization of organizations in the same field (as much in terms of structure as in processes, behaviours and culture) is explained by three forms of isomorphism:

- Mimetic isomorphism stems from uncertainty and bounded rationality; faced with this situation, organizations have a tendency to imitate one another. The uncertainty may take various forms. It may be related to the environment, particularly in a period of crisis or significant change. It may also be related to the objectives and goals of the organization, or to the usefulness and uses of a new technology, or of a future IS when the usefulness/use is vague or ambiguous. Uncertainty and bounded rationality influence organizations within the same field to imitate each other to be perceived as more legitimate. This imitation can 
also be unintentional, resulting from the transfer of employees and by the intervention of consultants or professional associations (DiMaggio \& Powell, 1983; Haveman, 1993; Mizruchi \& Fein, 1999).

- Normative isomorphism results from the professionalization of the members of the organization, that is to say, the whole of the collective efforts of a profession to define their skills and their work methods (Scott, 1995). While in a single organization the jobs are different from each other, they are very similar to the jobs of counterparts in other organizations (Di Maggio \& Powell, 1983). Two sources of normative isomorphism have been identified. On the one hand, by the standardization of educational curriculum (e.g. same training, same schools and universities, same skills). This source is encouraged by recruitment mechanisms which tend to always favour the same profiles. On the other hand, by the development of professional networks or organizational models which spread rapidly. Normative isomorphism leads to uniformity and consanguinity which can result, for example, in the adoption of common rules, languages and dress codes.

- Coercive isomorphism results from formal or informal political influence in a broad sense, exercised by the State, by organizations in the same field, or by societal cultural expectations. This political influence promotes adoption of common standards (Di Maggio \& Powell, 1983). For example, this is the case with the enactment of new environmental regulations (Jennings \& Zandbergen, 1995). These new rules influence the concerned organizations to consider a change, either to adapt, or to innovate. Thus, the organizational structures gradually reflect the rules and the dominant standards of a State or of a society (Slack \& Hinings, 1994).

In the context of our study, the theory of institutional isomorphism suggests that the decision to adopt or not to adopt an S.Scan IS can be explained by internal and external institutional pressures, and an organizations' goal of legitimacy within its field. Yet the influence of institutional pressures on pre-adoption - and more generally adoption - of an S.Scan IS has never been studied, and the literature on S.Scan does not explore the pressures and organizational need for legitimacy in its field to explain the decisions to adopt or not to adopt an S.Scan IS. Other more recent neo-institutionalist research extends the theoretical framework of institutional isomorphism and demonstrates that adoption of an IS can also respond to functional pressures, that is to say, to perceived problems in terms of performance and usefulness of institutional practices (Oliver, 1992). The literature on S.Scan, for its part, notes internal functional concerns to meet performance and competitiveness objectives. Some of these concerns can be drivers that promote pre-adoption. Other are barriers that, on the contrary, hinder or slow down pre-adoption.

\subsection{S.Scan drivers and barriers: a literature review to examine functional pressures that influence pre-adoption of an S.Scan IS}

Although often mobilized and studied, the concepts of drivers and barriers have not been explicitly defined in prior research (see for example Hofer, Hofer et al., 2011; Walker, di Sisto et al., 2008; Robson, Katsikeas et al., 2008). In this article we define them as follows:

- A driver is an internal or external pressure which influences the evaluation of a new S.Scan IS as a solution to the needs of the organization, and promotes its pre-adoption.

- A barrier is an internal or external pressure which influences the evaluation of a new S.Scan IS and slows or hinders its pre-adoption. 
No studies exist on the drivers for adoption and pre-adoption of an S.Scan IS. In contrast, an extensive literature focuses more generally on the managerial missions and objectives that support S.Scan and thus demonstrate the interest in performing S.Scan (see table 1). To the extent that the drivers are strategic intentions and wishes, in this article we equate them with functional, internal drivers, linked with the organizations' mission and performance and competitiveness goals, and likely to promote the pre-adoption of an S.Scan IS.

\begin{tabular}{l|l|l}
\hline \multicolumn{1}{c|}{ Driver } & \multicolumn{1}{c}{ Description } & \multicolumn{1}{c}{ Literature } \\
\hline Keep informed & $\begin{array}{l}\text { Stay informed to understand the current } \\
\text { environment and changes under way. }\end{array}$ & $\begin{array}{l}\text { Hambrick, 1981; Stubbart, 1982; Smircich \& } \\
\text { Stubbart, 1985; Raymond, Julien } \text { et al., 2001; } \\
\text { Lesca \& Caron-Fasan, 2008; Lesca, Caron-Fasan } \\
\text { et al., 2012. }\end{array}$ \\
\hline $\begin{array}{l}\text { Identify } \\
\text { threats }\end{array}$ & $\begin{array}{l}\text { Identify the threats/constraints and protect } \\
\text { the organisation }\end{array}$ & $\begin{array}{l}\text { Hambrick, 1981; Stubbart, 1982; El Sawy, 1985; } \\
\text { Lang, Calatone } \text { et al., 1997; Beal, 2000; Xu, Kaye } \\
\text { et al., 2003; Lesca, Caron-Fasan et al., 2012. }\end{array}$ \\
\hline $\begin{array}{l}\text { Identify } \\
\text { opportunities }\end{array}$ & $\begin{array}{l}\text { Identify opportunities to develop new } \\
\text { products/services/activities/markets, etc. }\end{array}$ & $\begin{array}{l}\text { Hambrick, 1981; Hambrick, 1982; Stubbart, } \\
\text { Beal, 2000; Xu, Kaye et al., 2003; Lesca, Caron- } \\
\text { Fasan } \text { et al., 2012. }\end{array}$ \\
\hline $\begin{array}{l}\text { Innovate } \\
\begin{array}{l}\text { Maintain a } \\
\text { competitive } \\
\text { position }\end{array}\end{array}$ & $\begin{array}{l}\text { Feed the innovation process to help } \\
\text { differentiate and improve competitiveness }\end{array}$ & $\begin{array}{l}\text { Raymond, Julien } \text { et al., 2001; Veugelers, Bury et } \\
\text { al., 2010. }\end{array}$ \\
\hline $\begin{array}{l}\text { Develop } \\
\text { sustain a competitive position }\end{array}$ & $\begin{array}{l}\text { Develop a new competitive advantage to } \\
\text { improve a competitive position }\end{array}$ & $\begin{array}{l}\text { Hambrick, 1981; Jennings \& Lumpkin, 1992; Wei } \\
\text { \& Lee, 2004. }\end{array}$ \\
\hline Anticipate & $\begin{array}{l}\text { Identify the emerging phenomena and } \\
\text { anticipate future changes and discontinuities } \\
\text { to act pro-actively and adapt strategy }\end{array}$ & $\begin{array}{l}\text { Hambrick, 1981; Choo, 2001; Lesca \& Caron- } \\
\text { Fasan, 2008; Lesca, Caron-Fasan } \text { et al., 2012 }\end{array}$ \\
\hline
\end{tabular}

Table 1: Synthesis of the literature on functional drivers that are likely to promote the pre-adoption of an S.Scan IS

Studies on barriers to adoption and pre-adoption of an S.Scan IS are also non-existent. However, a few studies have focused on failures and abandonment factors of S.Scan projects. Some of these factors relate to the actual sequence of events in the project and represent unforeseen complications that disrupt the design and implementation of the S.Scan IS, and are likely to significantly throw into question its deadlines, costs, objectives and profits for the organization (Doherty \& King, 2001). These factors for failure relate primarily to adoption and post-adoption, rather than to pre-adoption. Others, however, can contribute to explaining certain barriers likely to influence pre-adoption of an S.Scan IS (see table 2).

\begin{tabular}{l|l|l}
\hline \multicolumn{1}{c|}{ Barriers } & \multicolumn{1}{c}{ Description } & \multicolumn{1}{c}{ Literature } \\
\hline $\begin{array}{l}\text { Difficulty in } \\
\text { organizing the } \\
\text { process }\end{array}$ & $\begin{array}{l}\text { Lacking a standard method, organizations have } \\
\text { difficulty organizing the various stages of the S.Scan } \\
\text { process }\end{array}$ & $\begin{array}{l}\text { Calori, 1988; Yasai-Ardekani \& } \\
\text { Nystrom, 1996. }\end{array}$ \\
\hline Absence of impetus & $\begin{array}{l}\text { Management does not make the decision to engage } \\
\text { and to stimulate an S.Scan dynamic }\end{array}$ & Lesca \& Caron-Fasan, 2008. \\
\hline $\begin{array}{l}\text { Poor circulation of } \\
\text { information }\end{array}$ & $\begin{array}{l}\text { The interest of sharing information from S.Scan is not } \\
\text { understood } \\
\text { The structures for the dissemination of information } \\
\text { are inadequate }\end{array}$ & $\begin{array}{l}\text { Englewod \& Lenz, 1985; Ghoshal \& } \\
\text { 2008. }\end{array}$ \\
\hline
\end{tabular}




\begin{tabular}{|c|c|c|}
\hline $\begin{array}{l}\text { Hostile } \\
\text { organizational } \\
\text { culture }\end{array}$ & $\begin{array}{l}\text { An organizational culture hostile to or unwilling to } \\
\text { share and circulate information }\end{array}$ & $\begin{array}{l}\text { Diffenbach, 1983; Englewod \& Lenz, } \\
\text { 1985; Ghoshal \& Westney, 1991; } \\
\text { Babbar \& Rai, 1993; Lesca \& Caron- } \\
\text { Fasan, 2008. }\end{array}$ \\
\hline $\begin{array}{l}\text { Inappropriate } \\
\text { commitment of the } \\
\text { Management }\end{array}$ & $\begin{array}{l}\text { Lack of support and interest of the Management in } \\
\text { order to legitimize the S.Scan }\end{array}$ & Lesca \& Caron-Fasan, 2008. \\
\hline $\begin{array}{l}\text { Poor access to } \\
\text { information }\end{array}$ & $\begin{array}{l}\text { Difficulties accessing relevant information: } \\
\text { - either because the mobilized sources are unsuitable } \\
\text { - or because the information is buried in a mass of } \\
\text { data }\end{array}$ & El Sawy, 1985; Yoon, 2012. \\
\hline Lack of external aid & $\begin{array}{l}\text { Performing S.Scan is difficult without external } \\
\text { assistance }\end{array}$ & Lesca \& Caron-Fasan, 2008. \\
\hline $\begin{array}{l}\text { Difficulty } \\
\text { calculating ROI }\end{array}$ & Lack of methods to calculate the ROI of S.Scan & Prescott, 1999. \\
\hline $\begin{array}{l}\text { Lack of financial } \\
\text { resources }\end{array}$ & $\begin{array}{l}\text { An insufficient budget to internally or externally } \\
\text { mobilize the resources necessary for the S.Scan }\end{array}$ & $\begin{array}{l}\text { Ghoshal \& Westney, 1991; Lesca \& } \\
\text { Caron-Fasan, } 2008 .\end{array}$ \\
\hline Lack of time & $\begin{array}{l}\text { Lack of motivation of the actors which is reflected by } \\
\text { an inability to create time }\end{array}$ & $\begin{array}{l}\text { Diffenbach, 1983; Lesca \& Caron-Fasan, } \\
2008 .\end{array}$ \\
\hline Mis-alignment & $\begin{array}{l}\text { Mis-alignment of the S.Scan with the organizations' } \\
\text { strategy }\end{array}$ & Lesca \& Caron-Fasan, 2008. \\
\hline $\begin{array}{l}\text { Complexity of the } \\
\text { project }\end{array}$ & $\begin{array}{l}\text { Underestimation of the complexity of S.Scan } \\
\text { Over-estimation of the scope of S.Scan }\end{array}$ & Lesca \& Caron-Fasan, 2008. \\
\hline $\begin{array}{l}\text { Absence of clear } \\
\text { objectives }\end{array}$ & $\begin{array}{l}\text { Absence of a clear, shared definition of the objectives } \\
\text { of the S.Scan }\end{array}$ & Lesca \& Caron-Fasan, 2008. \\
\hline $\begin{array}{l}\text { Outside the } \\
\text { priorities of the } \\
\text { organization }\end{array}$ & $\begin{array}{l}\text { S.Scan is not part of the strategic priorities of the } \\
\text { organization }\end{array}$ & Lesca \& Caron-Fasan, 2008. \\
\hline
\end{tabular}

Table 2: Synthesis of the literature on barriers that are likely to hinder the pre-adoption of an S.Scan IS

\section{Research Methodology}

The objective of this study is to identify the drivers and barriers that influence the preadoption of an S.Scan IS. To do this, our study mobilizes a mixed methodology which combines sequential exploratory qualitative and quantitative research (Creswell, 2003). The exploratory nature of the research allows identification of important new variables. The sequential character of the methodology integrates the results of the qualitative study in the questionnaire during the quantitative phase. This research design thus allows producing new theoretical contributions when the theoretical framework is not (yet) sufficient to explain or understand the situations or the phenomena being studied (Creswell, 2003). The mixed methodology thus allows producing new theoretical contributions that a single methodology qualitative or quantitative - would not have been able to obtain, while strengthening the balance between depth and breadth of the study (Venkatesh, Brown et al., 2013, Creswell \& Clark, 2007).

This study focuses on a particular context: the sustainable supply chain (SSC). The decision to adopt an SSC is accompanied by various pressures which may be at the root of major organizational changes (Jennings \& Zandbergen, 1995; Connor \& Dovers, 2004; Bansal, 2005). This context of the SSC is particularly relevant for studying the pressures that explain the drivers and the barriers to the pre-adoption of a (new) S.Scan IS oriented toward SSC.

A first qualitative exploratory phase helped to identify the drivers and the barriers mentioned spontaneously by managers, and to discover new ones that were previously not identified in 
the literature. A second quantitative exploratory phase then allowed us to consolidate these first results to reveal the functional and institutional pressures. (i.e. Figure 1)

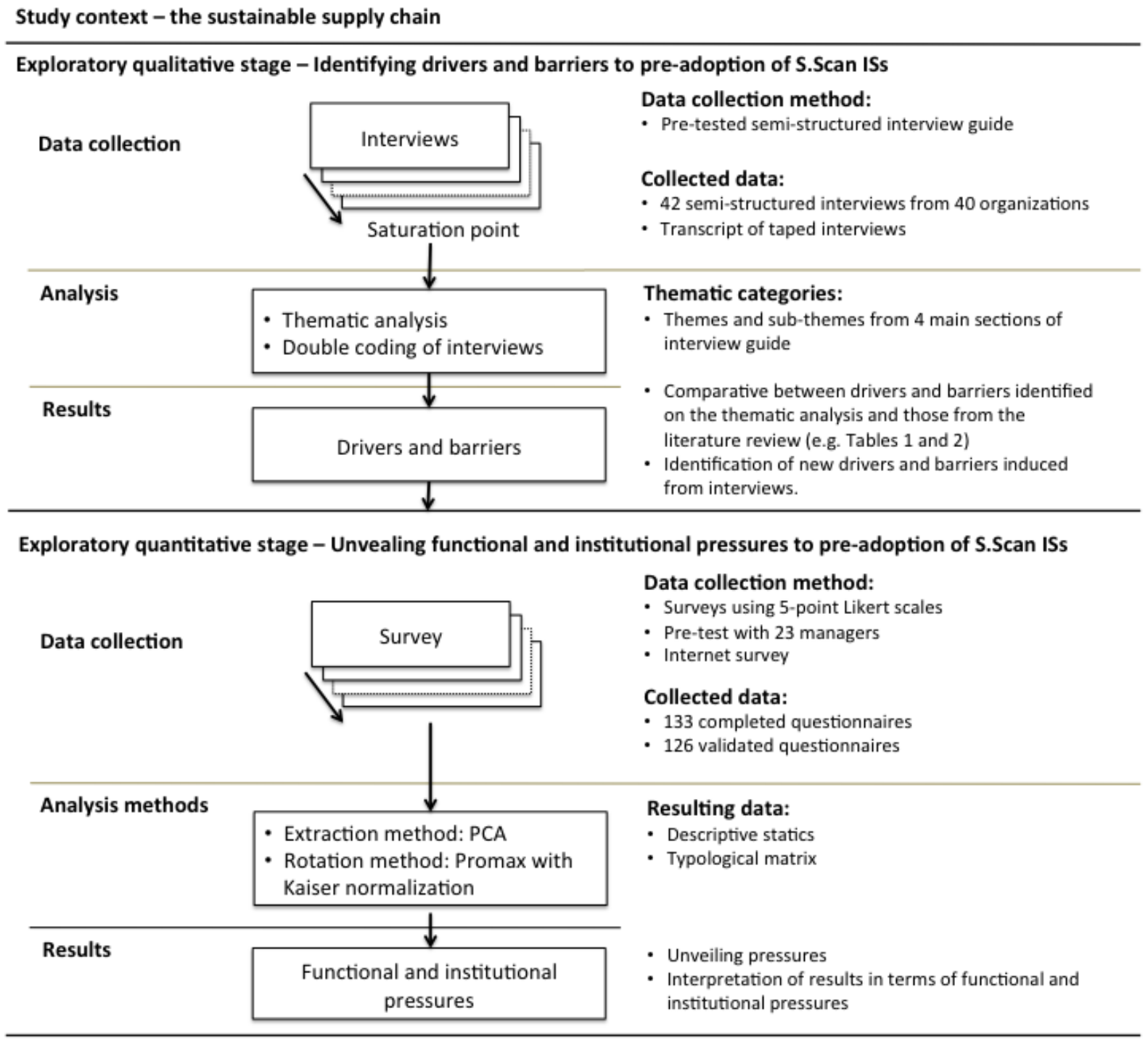

Figure 1: Research design

\subsection{Context of the study: the sustainable supply chain}

The context of the study is that of the sustainable supply chain. As a result of recent national and international institutional initiatives, organizations are encouraged to better take into account the problems of sustainable development (SD) in their operational activities and in particular to rethink their logistics schemas. However, many barriers impede the implementation of an SSC (Giunipero, Hooker et al., 2012). Some relate to the lack of information of managers concerning current or future legislation, as well as on the expected benefits and possible risks of such an approach (Walker, di Sisto et al., 2008). This lack of information is detrimental and often leads to choosing not to engage in SSC (Zhou, Cheng et al., 2000).

This study is part of a research project funded by the ADEME, the objective of which is to study the conditions of operationalization of an S.Scan applied to the SSC. Taking place over a period of three years, the project was structured around four key questions: what is S.Scan 
applied to SSCs? What are the current S.Scan practices in the field of SSC? How can the practices of S.Scan applied to SSC be developed? What are the barriers and drivers to S.Scan applied to SSCs? This article focuses only on the analysis of the last question.

\subsection{A qualitative exploratory phase to identify the drivers and barriers to pre- adoption of an S.Scan IS in the context of SSC}

In this first exploratory phase we conducted 42 semi-structured interviews between September 2010 and February 2011, with 50 people in 42 organizations from different sectors (see Appendix B), predominantly by telephone (31 interviews out of 42 , or $73.8 \%$ ), and to a lesser extent in face to face meetings (11 interviews, or $26.2 \%$ ). We thus sought to encounter the greatest possible diversity of interlocutors representative of the stakeholders in supply chains in France: industrial enterprises, commercial enterprises, logistics services providers (LSP), infrastructure managers, institutions which play a regulatory and planning role, and specialist consultants in the areas of research who are likely to influence the decisions of actors within the chains (see table 3). The objective was also to meet with competent individuals who are concerned by the subject. In light of the theme studied and its transversality, our interlocutors were likely to be part either of a logistical management, SD or IS/S.Scan, or close to the general management (see table 4). The interviews were conducted until saturation.

All the interviews were fully recorded and then transcribed and double coded on the basis of the coding grid constructed at the end of our literature review (see tables 1 and 2). However, new drivers and barriers also "emerged" from the analysis (Bardin, 2007) thus complementing the coding grid. The unit of analysis chosen for the thematic coding is interview. To assess the validity of the coding a rate of consistency, defined as the proportion of encodings coinciding between two coders, was calculated (Rust \& Cooil, 1994). The rate obtained shows a consistent average of $76.86 \%$, which is higher than the minimum rate of $70 \%$ recommended for this type of exploratory study (Nunnally \& Barnstein, 1994).

\subsection{A qualitative exploratory phase to identify the institutional and functional pressures to pre-adoption of an S.Scan IS in the context of SSC}

The questionnaire that we used (see Appendix C) incorporates all the drivers and barriers from both the literature review and the qualitative study (see tables 5 and 7). Each item was measured using a 5 point Likert scale ranging from "Strongly disagree" to "Strongly agree" to allow respondents to position themselves on a central point if they so wished. The questionnaire was subject to 23 pre-tests with managers who all have an interest either in logistics and SSC, or in S.Scan.

The profiles of the respondents are the same as those in the qualitative phase, namely: the head of logistics/supply chain, transport, SD/Corporate Social Responsibility (CSR) and S.Scan, as well as the general managers (see table 4) of the various stakeholders of the logistics chains in France (see table 3). Given that the study focuses on S.Scan applied to SSC, it was essential that the respondents have a sufficient level of knowledge concerning decisions related to S.Scan, logistics or SD.

The questionnaire was administered via the Internet using the SurveyMonkey platform between May and October 2012. After elimination of 263 incomplete questionnaires, 133 were retained. Seven respondents indicated that they had minor responsibilities and had little knowledge concerning decisions related to the whole of the areas addressed in our research. 
As a result their questionnaires were removed from the sample. Thus, 126 questionnaires were utilized and treated using SPSS software.

The data were analyzed using two methods of descriptive analysis. Initially, a univariate analysis (descriptive statistics around the mean, standard deviation and standard error of the mean) was performed in order, firstly, to highlight the relative importance of each driver and barrier relative to one another and, secondly, to measure the dispersion of the responses. Then a Principal Component Analysis (PCA) was used to complete the analysis of the average values of the responses and their dispersion and highlight the pressures influencing the preadoption of an S.Scan IS in the context of SSC.

\begin{tabular}{|c|c|c|c|c|}
\hline \multirow[t]{2}{*}{ Stakeholders } & \multicolumn{2}{|c|}{ Qualitative phase } & \multicolumn{2}{|c|}{ Quantitative phase } \\
\hline & $\mathrm{Nb}$ & $\%$ & $\mathrm{Nb}$ & $\%$ \\
\hline $\begin{array}{l}\text { Industrial enterprises } \\
\text { (SMI, Large industrial enterprises) }\end{array}$ & 13 & $31.0 \%$ & 27 & $21.4 \%$ \\
\hline $\begin{array}{l}\text { Commercial enterprises } \\
\text { (Mass retail, service SMIs, speciality hypermarkets) }\end{array}$ & 4 & $9.5 \%$ & 15 & $11.9 \%$ \\
\hline $\begin{array}{l}\text { LSP } \\
\text { (Large general LSP, LSP integrated with a distributor, commission } \\
\text { agents, other service providers) }\end{array}$ & 11 & $26.2 \%$ & 55 & $43.6 \%$ \\
\hline $\begin{array}{l}\text { Infra- and super- structure managers } \\
\text { (Port, infrastructure manager) }\end{array}$ & 3 & $7.1 \%$ & 3 & $2.4 \%$ \\
\hline $\begin{array}{l}\text { Institutions } \\
\text { (Ministry, region, inter-communal management union, city, } \\
\text { development partner, regional observatory, competitiveness } \\
\text { cluster and hub) }\end{array}$ & 5 & $11.9 \%$ & 5 & $4.0 \%$ \\
\hline $\begin{array}{l}\text { Providers of intangible services } \\
\text { (S.Scan company, IT providers for logistics, consultant specializing } \\
\text { in logistics) }\end{array}$ & 6 & $14.3 \%$ & 21 & $16.7 \%$ \\
\hline Totals & 42 & $100 \%$ & 126 & $100 \%$ \\
\hline
\end{tabular}

Table 3: Supply chain stakeholders interviewed during the two phases of research

\begin{tabular}{|c|c|c|c|c|}
\hline \multirow[t]{2}{*}{ Function / Department } & \multicolumn{2}{|c|}{ Qualitative phase } & \multicolumn{2}{|c|}{ Quantitative phase } \\
\hline & $\mathbf{N b}$ & $\%$ & $\mathbf{N b}$ & $\%$ \\
\hline $\begin{array}{l}\text { Logistics/ supply chain* } \\
\text { Transport /physical distribution* } \\
\text { Production / industrial management } \\
\text { Purchasing / Procurement } \\
\text { Research and development } \\
\text { Commercial / marketing } \\
\text { SD / CSR / quality, safety, environment * } \\
\text { S.Scan / Economic intelligence * } \\
\text { Information Systems } \\
\text { Directorate General } \\
\text { Other }\end{array}$ & $\begin{array}{l}\mathbf{1 0} \\
\mathbf{6} \\
1 \\
3 \\
- \\
3 \\
\mathbf{8} \\
\mathbf{4} \\
2 \\
\mathbf{8} \\
5\end{array}$ & $\begin{array}{c}20 \% \\
12 \% \\
2 \% \\
6 \% \\
- \\
6 \% \\
16 \% \\
8 \% \\
4 \% \\
16 \% \\
10 \%\end{array}$ & $\begin{array}{c}\mathbf{4 1} \\
\mathbf{1 1} \\
2 \\
12 \\
7 \\
11 \\
\mathbf{6} \\
2 \\
5 \\
\mathbf{3 0} \\
6\end{array}$ & $\begin{array}{c}30.8 \% \\
8.3 \% \\
1.5 \% \\
9 \% \\
5.3 \% \\
8.3 \% \\
\mathbf{4 . 5} \% \\
\mathbf{1 . 5} \% \\
3.7 \% \\
\mathbf{2 2 . 6 \%} \\
4.5 \%\end{array}$ \\
\hline Total & 50 & 100 & 126 & 100 \\
\hline
\end{tabular}

* Respondents at the core of the search target

Table 4: Directions of managers interviewed during the two phases of research

\section{Results}

The qualitative study allowed us to identify 31 drivers and barriers spontaneously mentioned during the interviews, including 10 that we had not identified in our literature review on 
S.Scan. Twelve of these (five of which were new) reflect the drivers for pre-adoption of an S.Scan IS (see table 5) and 19 (five of which were also new) reflect barriers (see table 7). The quantitative study reveals two pressures that motivate pre-adoption of an S.Scan IS (see table 6 ) and three which hinder it (see table 8). The results concerning drivers and barriers are presented separately.

\subsection{Pressures that help explain drivers and barriers to pre-adoption of an S.Scan IS in the context of SSC}

\begin{tabular}{|c|c|c|c|c|c|c|c|c|}
\hline \multirow{3}{*}{$\begin{array}{c}\begin{array}{c}\text { Literature } \\
\text { Review }\end{array} \\
1\end{array}$} & \multicolumn{4}{|c|}{ Qualitative exploratory study } & \multicolumn{4}{|c|}{ Quantitative exploratory study } \\
\hline & & $\begin{array}{l}2 \\
\text { Drivers } \\
\text { (items) }\end{array}$ & \multicolumn{2}{|c|}{$\begin{array}{l}3 \\
\text { Thematic } \\
\text { coding }\end{array}$} & \multirow[t]{2}{*}{$\begin{array}{c}4 \\
\text { Underlying question }\end{array}$} & \multicolumn{3}{|c|}{$\begin{array}{c}5 \\
\text { Descriptive statistics }\end{array}$} \\
\hline & & & $\mathrm{Nb}^{1}$ & $\%^{2}$ & & Mean & $\begin{array}{l}\text { Standard } \\
\text { deviation }\end{array}$ & $\begin{array}{l}\text { Standard } \\
\text { error of } \\
\text { the } \\
\text { mean }\end{array}$ \\
\hline No & 1 & By conviction & 4 & $9.5 \%$ & $\begin{array}{l}\text { We are convinced that we must } \\
\text { perform S.Scan for the SSC }\end{array}$ & 4.0 & 1.1 & .1 \\
\hline Yes & 3 & Keep informed & 33 & $78.6 \%$ & $\begin{array}{l}\text { We want to keep informed of ongoing } \\
\text { developments }\end{array}$ & 4.0 & 1.1 & .1 \\
\hline Yes & 10 & $\begin{array}{l}\text { Maintain a } \\
\text { competitive } \\
\text { position }\end{array}$ & 8 & $19.0 \%$ & $\begin{array}{l}\text { We seek to maintain our competitive } \\
\text { position }\end{array}$ & 4.0 & 1.1 & .1 \\
\hline Yes & 9 & Anticipate & 16 & $38.1 \%$ & $\begin{array}{l}\text { We seek to anticipate changes that } \\
\text { could affect us in order to be prepared }\end{array}$ & 4.0 & 1.0 & .1 \\
\hline Yes & 11 & Innovate & 11 & $26.2 \%$ & $\begin{array}{l}\text { We want to feed our innovation } \\
\text { process }\end{array}$ & 3.9 & 1.0 & .1 \\
\hline Yes & 7 & $\begin{array}{l}\text { Identify } \\
\text { opportunities }\end{array}$ & 12 & $28.6 \%$ & $\begin{array}{l}\text { We are looking to identify } \\
\text { opportunities }\end{array}$ & 3.8 & 1.0 & .0 \\
\hline Yes & 12 & Develop & 3 & $7.1 \%$ & $\begin{array}{l}\text { We wish to develop new markets / } \\
\text { new activities }\end{array}$ & 3.7 & 1.2 & .107 \\
\hline Yes & 8 & $\begin{array}{l}\text { Identify } \\
\text { threats }\end{array}$ & 4 & $9.5 \%$ & We are looking to identify threats & 3.7 & 1.1 & .1 \\
\hline No & 2 & $\begin{array}{l}\text { Ensure } \\
\text { compliance }\end{array}$ & 2 & $4.8 \%$ & $\begin{array}{l}\text { Performing S.Scan applied to SSC } \\
\text { helps us implicate our collaborators } \\
\text { in our SSC strategy }\end{array}$ & 3.5 & 1.1 & .1 \\
\hline No & 5 & Do as others do & 2 & $4.8 \%$ & $\begin{array}{l}\text { Other companies / organizations in } \\
\text { our sector perform S.Scan applied to } \\
\text { SSC }\end{array}$ & 3.5 & 1.2 & .1 \\
\hline No & 4 & Communicate & 3 & $7.1 \%$ & $\begin{array}{l}\text { By communicating on S.Scan applied } \\
\text { to SSC we avoid being made a bad } \\
\text { example of }\end{array}$ & 3.0 & 1.3 & .1 \\
\hline No & 6 & $\begin{array}{l}\text { Be inspired by } \\
\text { others }\end{array}$ & 20 & $47.6 \%$ & $\begin{array}{l}\text { We wait to see what others do } \\
\text { before we launch ourselves into } \\
\text { S.Scan applied to SSC }\end{array}$ & 1.9 & 1.0 & .1 \\
\hline
\end{tabular}

${ }^{1}$ Number of interviews in which each driver is mentioned

2 Percentage compared to the total number of interviews performed $=42$

Table 5: Drivers to pre-adoption of an S.Scan IS in the context of SSC

\subsubsection{Drivers to pre-adoption of an S.Scan IS in the context of SSC}

The thematic analysis of the interviews highlights a list of 12 drivers presented in column 2 of table 5 .

Seven are similar to the drivers presented in the literature (see table 5 column 1): to keep informed, identify opportunities, identify threats, anticipate, maintain a competitive position, 
innovate and develop. Five others are spontaneously mentioned during the interviews and are sometimes proportionally discrete, but are not identified in previous studies in the field of the S.Scan.

Two of these five drivers are characterized by a strong contrast between the results of the qualitative and quantitative studies:

- by conviction: "It is cultural at a given time, I would say that we don't ask ourselves the question ... " [Large industrial enterprise]. Spontaneously mentioned in four interviews, this is the driver which was most strongly agreed upon in the questionnaire (mean 4.0 ; standard deviation 1.1)

- be inspired by others: "They invest pretty well and in general, they have good initiatives, therefore they are the people that we look at. We watch them, in reality we are not really comparable in terms of activity, of course we cannot assimilate (their practices), but they do things which can sometimes inspire us or (have the) means that can inspire us" (LSP). Paradoxically, this driver is mentioned spontaneously by half of the interviewees (20 people of 42), but it is the subject of strong disagreement in the quantitative study (mean 1.9 ; standard deviation 1.0 )

Two other of these five drivers are, on the other hand, mentioned in a more discreet manner in the exploratory phase, with a globally positive level of agreement in the quantitative study:

- ensure compliance: "For me, encouraging people to be aware of everything that is happening around them and to give them the opportunity to pass on the info, and additionally show them that that reverberates with others, it's great for staff motivation" [Commercial enterprise] (mentioned in 2 interviews of 42 ; mean 3.5 in the quantitative study with a standard deviation of 1.1 )

- do as others do: "We work a lot by benchmark, I try to watch a little what the big guys do, the leaders, or what is being said in the press, things like that, to see if it applies to us. Perhaps it's kind of a special 'copy/paste' culture" [Small industrial enterprise] (mentioned in 2 interviews of 42 ; mean 3.5 in the quantitative study with a standard deviation of 1.2 )

The fifth driver is also occasionally spontaneously evoked in the exploratory phase, and its level of agreement is not significant, although the standard deviation shows contrasting levels of agreement depending upon the respondents:

- communicate: "Scanning is merely a way to communicate what is there, but if it is to communicate studies, it's not very interesting, however, communicating accomplishments that allow you to move ahead, and that will allow companies which have not yet done so to do so, that seems important to me!" [Small industrial enterprise] (mentioned in 3 interviews of 42 ; mean 3.0 in the quantitative study with a standard deviation of 1.3 )

\subsubsection{Pressures that drive pre-adoption of an S.Scan IS in the context of SSC}

The PCA suggests a solution of two or three components. We have retained the two component solution because it presents superior coherence and relevance ${ }^{1}$. The results of the

\footnotetext{
${ }^{1}$ A first step of analysis checks the consistency of the set of items allowing us to create a good factor structure. The MSA coefficient of the diagonal of the anti-image matrix should present coefficients above 0.5 in order to confirm that the variables are well adapted to the structure of the other variables. Given that the MSA coefficient is less than 0.5 for item 6 (0.392), deletion of this item should be considered, although it is not essential, because the quality of representation of this item was otherwise correct.
} 
analysis in two main components are presented in table 6. They reveal two main pressures for pre-adoption:

- The first pressure refers to the search for a form of "proactivity". Here, the organizations show a desire to anticipate changes to come. Their attitude is truly proactive and shows a willingness to develop new markets and/or to feed their innovation process. This component is built from "We want to feed our innovation process" (0.845), "We seek to identify threats" (0.787), "We seek to identify opportunities" (0.775), "We seek to maintain our competitive position" (0.762), "We wish to develop new markets / new activities" (0.694) and "We seek to anticipate changes that could affect us in order to be prepared" (0.676). This component shows that the pre-adoption of an S.Scan IS in the context of SSC is positively influenced (driven) by a functional pressure of competitiveness.

- The second pressure refers to a form of "conformism". The organizations have an attitude of follower in seeking to keep informed about what already exists. S.Scan ISs are also regarded as an internal tool for management (to motivate employees). This leads to questioning real motivations, especially when some respondents need an S.Scan IS in order to not be "shamed". This component is constructed from: "Other companies / organizations in our sector perform S.Scan applied to the SSC" (0.846), "Performing S.Scan applied to the SSC helps us implicate our collaborators in our SSC strategy" (0.819), "We want to keep informed of ongoing developments" (0.788), and to a lesser extent "By communicating on S.Scan applied to the SSC we avoid being made a bad example of" (0.692). This component shows that the pre-adoption of an S.Scan IS in the context of SSC is positively influenced (driven) by an institutional pressure of conformism.

\begin{tabular}{|c|c|c|c|}
\hline \multirow{2}{*}{\multicolumn{2}{|c|}{$\begin{array}{l}\text { Typological matrix with } 2 \text { factors } \\
\text { Pressures: pressures / drivers / underlying questions }\end{array}$}} & \multicolumn{2}{|c|}{ Component } \\
\hline & & 1 & 2 \\
\hline \multicolumn{4}{|c|}{ Functional pressure: competitiveness (search for a form of "pro-activity ") } \\
\hline 11 Innovate & We want to feed our innovation process & .845 & \\
\hline 8 Identify & We seek to identify threats & .787 & \\
\hline $\begin{array}{l}7 \text { Identify } \\
\text { opportunities }\end{array}$ & We are looking to identify opportunities & .775 & \\
\hline $\begin{array}{l}10 \text { Maintain a competitive } \\
\text { position }\end{array}$ & We seek to maintain our competitive position & .762 & \\
\hline 12 Develop & We wish to develop new markets / new activities & .694 & \\
\hline 9 Anticipate & We seek to anticipate changes that could affect us in order to be prepared & .676 & \\
\hline \multicolumn{4}{|c|}{ Institutional pressure: conformism (search for a form of "conformism") } \\
\hline 5 Do as others do & Other companies / organizations in our sector perform S.Scan applied to SSC & & .846 \\
\hline 2 Ensure compliance & $\begin{array}{l}\text { Performing S.Scan applied to SSC helps us implicate our collaborators in our SSC } \\
\text { strategy }\end{array}$ & & .819 \\
\hline 3 Keep informed & We want to keep informed of ongoing developments & & .788 \\
\hline 1 By conviction & We are convinced we must perform S.Scan for the SSC & & .701 \\
\hline 4 Communicate & By communicating on S.Scan applied to SSC we avoid being made a bad example of & & .692 \\
\hline
\end{tabular}

When the PCA is performed, the minimum residual factor method of the variance (i.e. minimum threshold of $60 \%$ of explained variance) shows a solution in 3 factors. After Promax rotation in order to improve the results of the PCA, the three factors were identified. However, item 6 was the only item constituting the third factor. In addition, its negative correlation reveals that it constitutes a measure having a different meaning from the other two factors. This result confirms the earlier question concerning deletion of this item. After its removal, a new PCA was performed. The two factor solution was confirmed by the percentage of residual variance $(59.99 \%$ of variance explained with two factors). 
Table 6: Typological matrix resulting from factorization of drivers to pre-adoption of an S.Scan IS in the SSC context

\subsection{Functional pressures that help explain barriers to pre-adoption of an S.Scan IS in the SSC context}

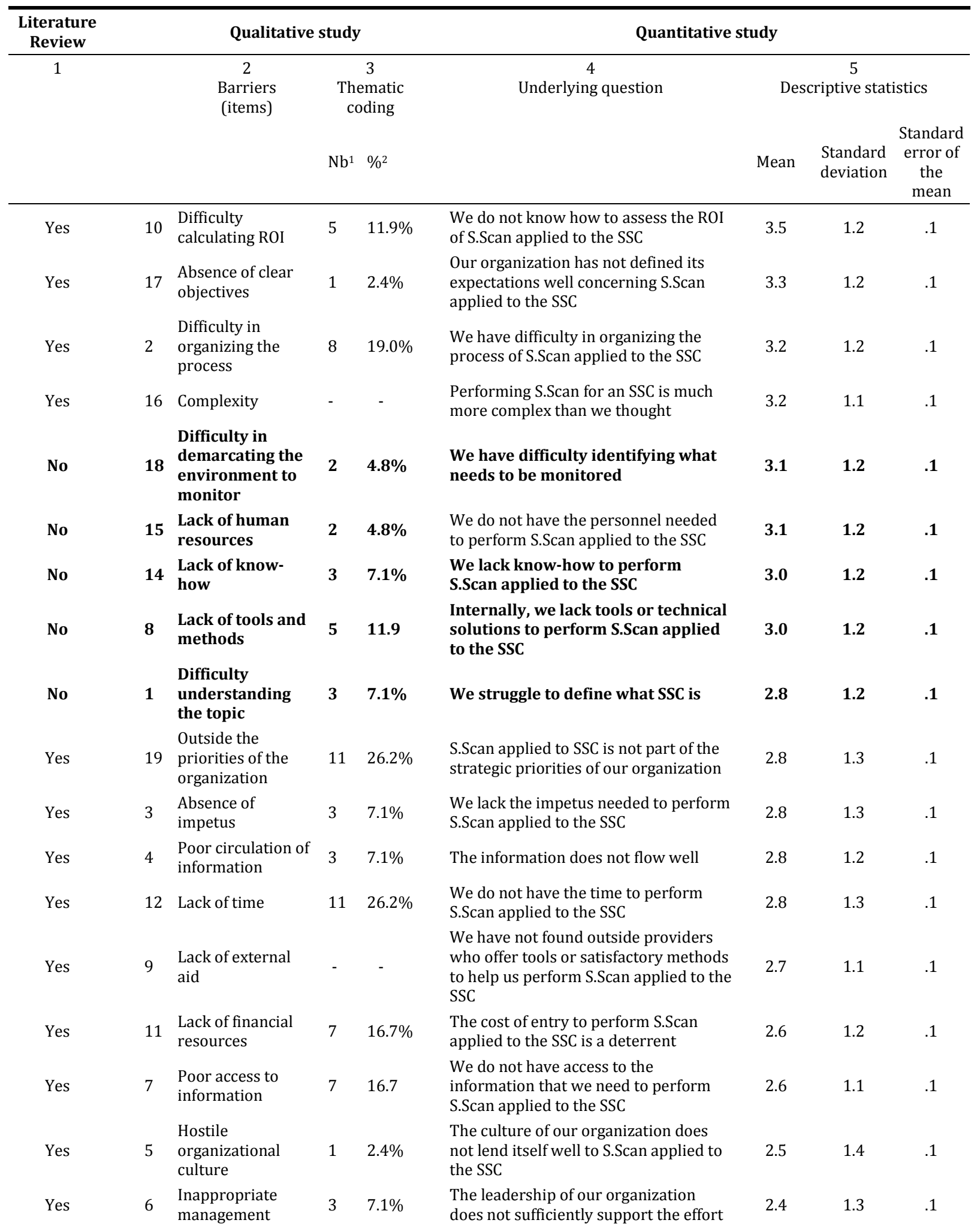




\begin{tabular}{|c|c|c|c|c|c|c|c|c|}
\hline & & commitment & & & of S.Scan applied to the SSC & & & \\
\hline Yes & 13 & Mis-alignment & - & - & $\begin{array}{l}\text { S.Scan applied to the SSC is not } \\
\text { consistent with the strategy of our } \\
\text { organization }\end{array}$ & 2.1 & 1.1 & .1 \\
\hline
\end{tabular}

${ }^{1}$ Number of interviews in which each barrier is mentioned

2 Percentage compared to the total number of interviews performed $=42$

\section{Table 7: Barriers to pre-adoption of an S.Scan IS in the context of SSC}

\subsubsection{Barriers to pre-adoption of an S.Scan IS in the context of SSC}

The thematic analysis of the interviews highlights a list of 19 barriers presented in column 2 of table 7. This list is globally consistent with the barriers mentioned in prior research. Five new barriers nevertheless emerge from the qualitative study. They were infrequently evoked spontaneously in the exploratory phase, and their level of means agreement is average, although the standard deviation shows contrasting levels of agreement depending upon the respondents (see table 7 column 1):

- Difficulty in demarcating the environment to monitor "It's true, if it's not well targeted! They can get lost, and as a result, I think that they can say to themselves, well, it's too complicated" [Institutional] (mentioned in 2 interviews of 42 ; mean 3.1 in the quantitative study with a standard deviation of 1.2 )

- Difficulty understanding the topic: "Frankly, I don't really know how to define it! How do you define it? ... I'm curious!" [Large industrial enterprise] (mentioned in 3 interviews of 42 ; mean 2.8 in the quantitative study with a standard deviation of 1.2)

- Lack of tools and methods: "The difficulty is, well, how to organize the scanning, you know ... how to organize the figures, that is to say, hold on to the important information and let go of what is less important, how to incorporate it, and how we'll deal with it" [Infrastructure manager] (mentioned in 5 interviews of 42 ; mean 3.0 in the quantitative study with a standard deviation of 1.2)

- Lack of know-how: "We subcontract, we don't know how to do it" [Infrastructure manager] (mentioned in 3 interviews of 42 ; mean 3.0 in the quantitative study with a standard deviation of 1.2)

- Lack of human resources: "We would be interested in a research department, and in addition to the department heads, someone in charge of the project who gathers, structures a whole set of databases, that's what I wish we had, it is something that I don't have... on that front, the service is not strong enough," [Infra- and super- structures manager ] (raised in 2 interviews of 42 ; mean 3.1 in the quantitative study with a standard deviation of 1.2)

\subsubsection{Functional pressures that hinder pre-adoption of an S.Scan IS in the context of SSC}

The PCA (see table 8) suggests a three component construction to characterize the barriers to pre-adoption of an S.Scan IS ${ }^{2}$ :

\footnotetext{
${ }^{2}$ The MSA coefficient of the diagonal of the anti-image matrix presents coefficients above 0.5 for all the items, confirming that each item is well adapted to the structure of the other variables.

The minimum residual factor method of the variance and the method of Eigen values showed a solution in three factors. After Promax rotation, the three factors were identified, with the exception of item 16 ("Doing S.Scan applied to the SSC is much more complicated than we thought") which correlates with two factors and with negative direction. This result could be explained by the formulation of this item which is very broad on the
} 
- The first component focuses on the "Lack of resources and skills for S.Scan applied to the $S S C^{\prime \prime}$. This component highlights the difficulties for an organization to identify and mobilize internal as well as external human resources and methodological resources. It is primarily composed of: "Internally, we lack tools or technical solutions to perform S.Scan applied to the SSC" (0.921), "We have not found outside providers who offer tools or satisfactory methods to help us perform S.Scan applied to the SSC" (0.810), "We lack the impetus needed to perform S.Scan applied to the SSC" (0.721), "We do not have access to the information that we need" (0.692), and to a lesser extent "We do not have the personnel needed to perform S.Scan applied to the SSC" $(0,615)$, "The cost of entry to perform S.Scan applied to the SSC is a deterrent" (0.604) and finally "The information does not flow well" (0.570). This component shows that pre-adoption of an S.Scan IS in the context of SSC is negatively influenced (hindered) by a functional pressure for efficiency.

- The second component focuses on the "Difficulty to define the expectations and objectives". This component highlights the difficulty for organizations to engage in S.Scan due to a lack of knowledge regarding what to expect and how to organise in order to be effective. It is composed primarily of: "We have difficulty in organizing the process of S.Scan applied to the SSC" (0.825), "We struggle to define what SSC is" (0.768), "We do not know how to assess the ROI of S.Scan applied to the SSC" (0.723), and to a lesser extent "We do not have the time to perform S.Scan applied to the SSC" (0.689), "We have difficulty identifying what needs to be monitored" (0.642) and "Our organization has not defined its expectations well concerning S.Scan applied to the SSC" (0.434). This component shows that pre-adoption of an S.Scan IS in the context of SSC is negatively influenced (hindered) by a functional pressure for performance.

- The third component deals with "Mis-alignment between S.Scan applied to the SSC and the strategy". At odds with the strategic priorities of the organization and without support of the governing bodies, S.Scan has no legitimacy. It is composed of: "S.Scan applied to the SSC is not part of the priorities of our organization" (0.845), "The leadership of our organization does not sufficiently support the effort of S.Scan applied to the SSC" (0.811), "The culture of our organization does not lend itself well to S.Scan applied to the SSC" (0.776) and "S.Scan applied to the SSC is not consistent with the strategy of our organization" (0.763). This component also shows that pre-adoption of an S.Scan IS in the context of SSC is negatively influenced (hindered) by a functional pressure for performance.

\begin{tabular}{|c|c|c|c|c|}
\hline \multirow{2}{*}{\multicolumn{2}{|c|}{$\begin{array}{l}\text { Typological matrix with three factors without item } 16^{\mathrm{a}} \\
\text { Pressures: pressures / barriers / underlying questions }\end{array}$}} & \multicolumn{3}{|c|}{ Components } \\
\hline & & 1 & 2 & 3 \\
\hline \multicolumn{5}{|c|}{ Functional pressure: efficiency (lack of resources and skills for S.Scan applied to the SSC) } \\
\hline 8 Lack of tools and methods & $\begin{array}{l}\text { Internally, we lack tools or technical solutions to perform S.Scan applied to } \\
\text { the SSC }\end{array}$ & .921 & & \\
\hline 9 Lack of external aid & $\begin{array}{l}\text { We have not found outside providers who offer tools or satisfactory methods } \\
\text { to help us perform S.Scan applied to the SSC }\end{array}$ & .810 & & \\
\hline 3 Absence of impetus & We lack the impetus needed to perform S.Scan applied to the SSC & .721 & & \\
\hline 7 Poor access to information & $\begin{array}{l}\text { We do not have access to the information that we need to perform S.Scan } \\
\text { applied to the SSC }\end{array}$ & 692 & & \\
\hline 15 Lack of human resources & We do not have the personnel needed to perform S.Scan applied to the SSC & .615 & & \\
\hline
\end{tabular}

aspect of "complexity". The researchers chose to delete this item in order to obtain the most obvious solution with three factors and to perform a new PCA without it. 


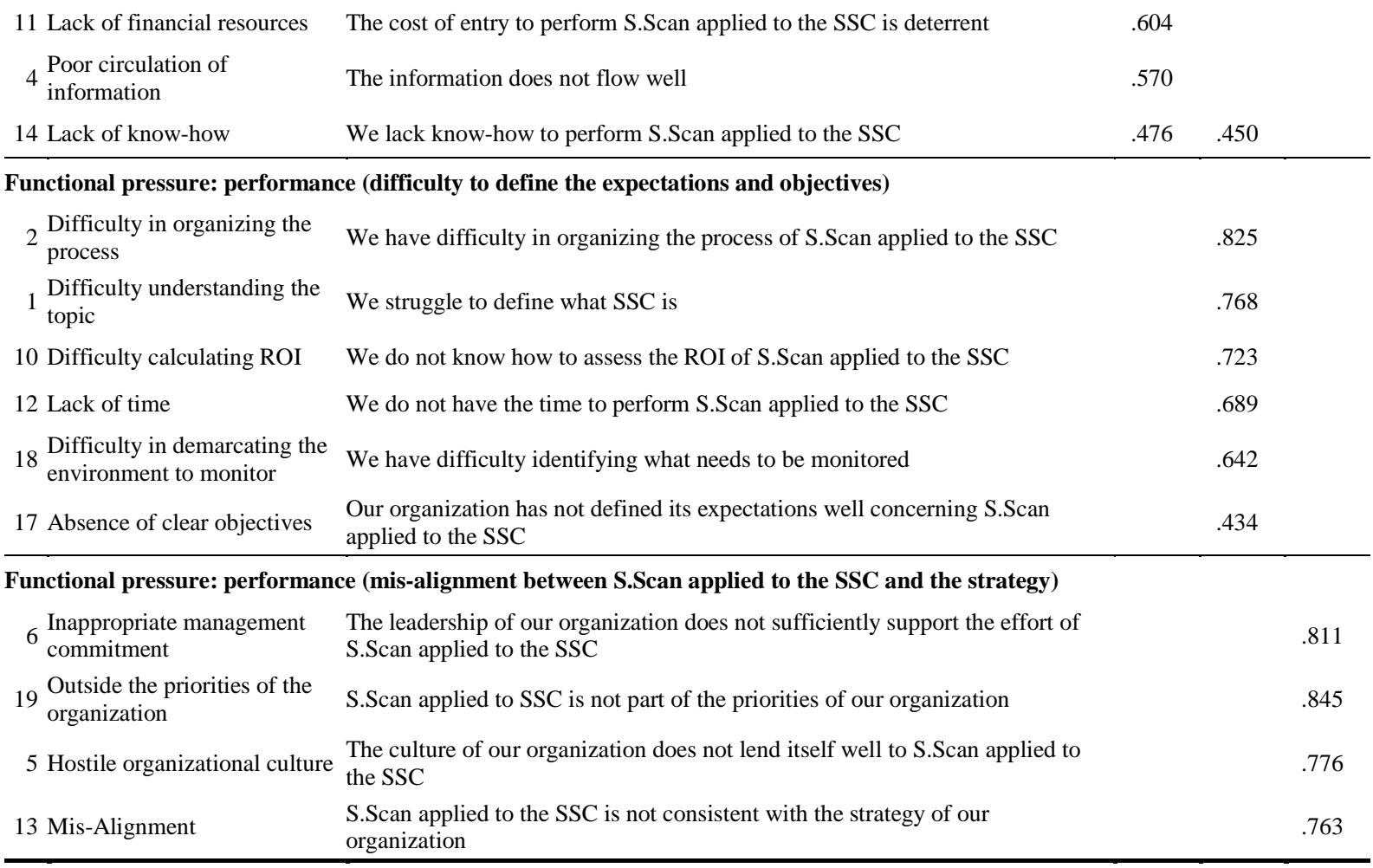

Extraction Method: PCA.

Rotation Method: Promax with Kaiser normalization.

a. The rotation converged in 7 iterations.

\section{Table 8: Typological matrix resulting from factorization of barriers to pre-adoption of an S.Scan IS in the context of SSC}

\section{Discussion}

The SSC context constitutes a limit to studying the drivers and the barriers which influence pre-adoption of an S.Scan IS because the "authorised" discourses have not yet really emerged, the rules and standards have not yet been established. This observation thus opens two perspectives for complementary research to deepen the understanding of the pre-adoption of an S.Scan IS:

- replicate our study in more mature contexts than is currently the case of SSC, to deepen the understanding of institutional pressures, namely normative ones, that this first study has not allowed us to explore, and their influences on the drivers and barriers to the preadoption of an S.Scan IS;

- conduct new studies on a field under construction, as with for example the case of SSC or Big data, in light of the organizing vision model (Carton-Bourgeois, De Vaujany et al., 2003 ; Burton Swanson \& Ramiller, 2004) to understand how the "authorized" discourses which emerge within a professional community influence the barriers and the drivers to pre-adoption of an S.Scan IS.

Nevertheless, despite these limitations, the SSC context has helped reveal the influence of certain institutional pressures on the pre-adoption of an S.Scan IS. This research suggests that S.Scan IS pre-adoption can be subject to both functional and institutional pressures. The first reflect on performance objectives, while the second reflect objectives of legitimacy (see table 9). 


\begin{tabular}{|c|c|c|}
\hline Pressures & Drivers & Barriers \\
\hline $\begin{array}{l}\text { Functional } \\
\text { (Performance) }\end{array}$ & $\begin{array}{l}\text { Competitiveness } \\
\text { Search for a form of pro-activity } \\
>\text { The pre-adoption of an S.Scan IS may be } \\
\text { motivated by strategic concerns for } \\
\text { competitiveness and organizational } \\
\text { sustainability. }\end{array}$ & $\begin{array}{l}\text { Performance } \\
\text { Mis-Alignment } \\
\text { > The pre-adoption of an S.Scan IS can be hindered } \\
\text { when its purpose (i.e. the SSC in our study) is not a } \\
\text { strategic priority for the organization. } \\
\text { > Difficulty defining expectations and objectives } \\
\text { Pre-adoption of an S.Scan IS can be hindered when } \\
\text { the usefulness of the system is not clearly defined or } \\
\text { understood. } \\
\text { Efficiency } \\
\text { Lack of resources and skills } \\
\text { > Pre-adoption of an S.Scan IS can be hindered when } \\
\text { the organization does not have the necessary } \\
\text { resources (i.e. human, methodological, technological, } \\
\text { financial, informational) to implement the system, or } \\
\text { when it does not intend to invest in the system. }\end{array}$ \\
\hline $\begin{array}{l}\text { Institutional } \\
\text { (Legitimacy) }\end{array}$ & $\begin{array}{l}\text { Conformism } \\
\text { Search for a sort of conformism } \\
>\text { Pre-adoption of an S.Scan IS may be } \\
\text { motivated by a need for legitimacy of an } \\
\text { organization in a field, either by } \\
\text { conviction (i.e., the SSC in our study), or in } \\
\text { order to do as others do. }\end{array}$ & $\begin{array}{l}\text { Coercion } \\
\text { Absence of regulatory incentives } \\
\text { > The lack of priorities, expectations, objectives, and } \\
\text { clear and enduring rules on the part of the State (in } \\
\text { particular), can hinder the development of the SSC in } \\
\text { organizations, and therefore hinder the pre-adoption } \\
\text { of an S.Scan IS oriented toward an SSC. }\end{array}$ \\
\hline
\end{tabular}

\section{Table 9: Summary of the pressures that are likely to influence the pre-adoption of an S.Scan IS}

The functional pressures show that pre-adoption of an S.Scan IS may be motivated by the objectives of competitiveness and sustainability, while the purpose of the system (the consideration of sustainable development in supply chains in the context of our study) is consistent with the strategic priorities of the organization. They also show that pre-adoption can be hindered: when the objectives of the S.Scan IS are not clearly defined and consistent with the priorities of the organization; when its usefulness and effectiveness in support of the achievement of the objectives of the organization are not guaranteed especially in terms of return on investment; when the organization does not have the necessary resources to implement and then put into production such an IS, or even when it has the resources but that mobilizing for an S.Scan IS is not a priority. These functional pressures are consistent with the literature on barriers and drivers in the S.Scan field. But they instantiate, complement and structure (in the theoretical framework of adoption) knowledge on S.Scan which up to now has been more general, diffuse and vague in the literature (see tables 1 and 2).

More generally, these functional pressures that influence the pre-adoption of an S.Scan IS are also consistent with the literature on IS adoption. However, our study completes and clarifies the state of current knowledge on IS pre-adoption (Hameed, Counsell et al., 2012). Thus, among the 19 barriers that we have identified:

- Nine barriers have already been identified in the literature as having an influence on the adoption and/or post-adoption decision phases, but their influence (hindrance) in the preadoption phase was not identified until now (Hameed, Counsell et al., 2012). They focus either on organizational characteristics (i.e. mis-alignment, a lack of impetus, no clear objective, poor circulation of information, a lack of financial resources, poor access to 
information and a hostile organizational culture), or on the characteristics of the new IS (i.e. difficulty calculating ROI for an IS), or even on the characteristics of the external environment (i.e. lack of external aid, for example S.Scan providers).

- Two other barriers seem never to have been identified in the overall adoption process. The first concerns the difficulty to define the perimeter of the IS (i.e. the difficulty to demarcate the environment to monitor), that is to say, identification of the organization's strategic priorities, the areas of activity concerned, and the information needs that should be addressed by the future IS. If the perimeter is imprecise, either too wide or too narrow, the usefulness of a future IS is not convincing. The second obstacle concerns the understanding of the mission of the IS when it relates to an emerging thematic which itself is not understood. In the context of this study, the participants did not understand the "sustainable supply chain" thematic (i.e. difficulty in understanding the SSC topic). Often, they did not understand how it concerned their activity, nor the potential stakes for their organization. In other contexts, there could be emerging topics about which the "authorized" discourses are not yet stabilized, thus understanding is still fragile and weakly shared, the practices are isolated and emerging, and the usefulness of an IS unknown to the organization (e.g. Big data). Future research will allow considering the relevance of these two barriers for the adoption of ISs in general.

Institutional pressures, on the other hand, show that the pre-adoption of an S.Scan IS is neither exclusively, nor necessarily a rational decision. It may also be the result of internal and external influences, which can motivate an organization to strengthen its legitimacy in its field. Either when its internal stakeholders are convinced of a mission - for example the design of sustainable supply chains in the context of our study - and of the usefulness of an S.Scan IS to improve the organization's capacity to identify and propose solutions and innovations relevant to carrying out this mission. Or when the organization experiences strong pressures to comply with the trends and developments in its field from its external stakeholders, and needs to improve its ability to identify, understand and anticipate in order to react and adapt to these pressures.

The study of pre-adoption of an S.Scan IS from the neo-institutional perspective, and more specifically using the theory of institutional isomorphism, shows the limits of the functional and strategic perspective currently dominant in the field of S.Scan. It also highlights the need to expand the framework of analysis to take into consideration more institutional drivers and barriers. More specifically, our study shows that the decision to adopt or not to adopt an S.Scan IS can also be explained by a form of mimetic isomorphism. But implicitly, although not evident in our results, the political context in which we conducted our study raises questions on the influence of a coercive isomorphism.

Indeed, at the moment our research project was retained and approved by the PREDIT and the ADEME, France had committed to reducing its greenhouse gas emissions by $20 \%$ by 2020 and by $75 \%$ by 2075 (factor 4). However, since 2010, the translation of these objectives in the transport sector has been much less clear. In a context of economic crisis and of very low growth, successive governments have repudiated these initiatives and the national priorities have changed several times. Political speeches have been contradictory and the regulatory incentives announced have not been implemented or have been abandoned. The greenhouse gas emitted to manufacture and transport products to France have not ultimately been taken into account in the follow-up. Overall, the means for implementation have not been clearly identified. So much so that in phase 1 of our study (qualitative exploratory), many of the interviewees explained having interpreted the instability of the coercive pressure as a sign of a disavowal by the government. In the face of uncertainty as to the measures to be implemented, many abandoned their initiatives in terms of SSC, pending clarification of the 
objectives and the policy incentives. In such a context, the pre-adoption of an S.Scan IS to support an SSC approach is necessarily hindered by the absence of coercive pressure on the part of the State.

This could also explain why in phase 2 of our study (quantitative exploratory), despite our efforts to widely disseminate our questionnaire and administer it on a large scale (with the main professional networks, but also via several academic networks of specialized graduate training programs), our investigation mobilized few logistics and supply chain professionals. At the time we undertook our investigation, the SSC was no longer a relevant topic for the majority of the organizations surveyed; pre-adoption of an SSC oriented S.Scan was not a priority. Yet, despite the absence of coercive pressure on the part of the State to motivate a commitment to SSC and, therefore, the pre-adoption of an S.Scan IS, the organizations also faced potential pressures from their supply chain partners, as well as from their clients. However, in the 42 exploratory interviews that we conducted with representatives of all the supply chain stakeholders, and in diversified sectors (public and private, B2B and B2C), none of the individuals interviewed mentioned such coercive or normative pressure to explain either the drivers or the barriers for their organization in the development of the SSC and the pre-adoption of an S.Scan IS for an SSC.

From a methodological point of view this study also illustrates, in the IS field, the interest of a multi-method research design which combines study depth and breadth in order to explore an as yet little-known subject (i.e. pre-adoption of an S.Scan IS) in a new context (i.e. sustainable supply chain). In this research, the qualitative exploratory phase allowed us to deeply examine the drivers and barriers which influence pre-adoption of a new S.Scan IS, to identify new items not yet documented by the literature in the S.Scan field, and to then reveal new components in the quantitative exploratory phase. For example, four of the five drivers which make up the "conformism" component are derived from the qualitative exploratory phase. Without this qualitative exploratory phase, conformism could not have been identified as one of the institutional pressures that can influence the pre-adoption of an S.Scan IS. The quantitative exploratory phase, for its part, because of its basis on a sample of greater breadth, reveals an underlying structure of the drivers and barriers, and strengthens the validity of the five functional and institutional pressures identified in this study.

\section{Conclusion}

This study provides two major lessons that can inform organizations in the pre-adoption phase of an S.Scan IS, as well as public actors (i.e. States, communities) wishing to induce firms to better take into account the issues of sustainable development in their supply chain activities. First of all, if the pre-adoption of an S.Scan IS is explicitly motivated in organizations by competitive objectives, it is, however, hindered when the S.Scan IS is understood to be a functional IS. These results mean that in the pre-adoption phase, it is preferable to view an S.Scan IS as a support to the strategy, without worrying about the resources for implementing it. In other words, it is preferable to ensure that the strategy and objectives of the organization are clearly defined, and that an S.Scan IS could make a positive contribution. Then, taking into account the influence of conformist and coercive pressures on the pre-adoption of an SSC oriented S.Scan IS, our results show that the public actors have two levers by which to influence organizations over time. On one hand, identifying and disseminating best practices to feed and orient mimetic pressures, and on the other hand, defining the political orientations, objectives and a clear and stable regulatory framework sufficient to put coercive pressure on the organizations. 


\section{Thanks}

The authors thank the PREDIT 4 and the ADEME for their confidence and funding for this research project. Our thanks also to the members of the VLD Project for their contribution to the data collection and analysis: Nathalie Fabbe-Costes, Cendrine Fons, Anne Rollet, Christine Roussat, Stéphane Sirjean (CRET-LOG), Blandine Ageron, Olivier Lavastre, (CERAG), Isabelle Burdin (Cluster Paca-Logistique).

\section{References}

Abdennadher S., Cheffi W. (2011), "L'adoption du vote par internet aux assemblées générales des actionnaires de sociétés cotées en France : une perspective institutionnaliste", Systèmes d'Information et Management, Vol. 16, n², p. 35-71.

Amabilé S., Meissonier R., Haller C., Boudrandi S. (2012), "Capacité d'absorption des informations et pratiques de veille stratégique dans les PME : une étude sur des domaines vitivinicoles provençaux", Systèmes d'Information et Management, Vol. 17, n³, p. 111-142.

Babbar S., Rai A. (1993), "Competitive intelligence for international business", Long Range Planning, Vol. 26, n³, p. 103-113.

Bansal P. (2005), "Evolving sustainably: a longitudinal study of corporate sustainable development”, Strategic Management Journal, Vol. 26, n³, p. 197-218.

Bardin L. (2007), L'analyse de contenu, Presses Universitaires de France, Paris.

Baskerville R., Pries-Heje J. (2001), “A multiple theory analysis of a diffusion of information technology case”, Information Systems Journal, Vol. 11, nº3, p. 181-212.

Baumard P. (1997), "L'information stratégique dans la grande organisation", Systèmes d'Information et Management, $\mathrm{Vol} 2, \mathrm{n}^{\circ} 2, \mathrm{p} 3-25$

Beal R. (2000), “Competing Effectively: Environmental Scanning, Competitive Strategy, and Organizational Performance in Small Manufacturing Firms", Journal of small business management, Vol. 38, ${ }^{\circ} 1$, p. 27-47.

Belmondo C. (2008), “Comprendre les pratiques des acteurs de l'intelligence économique : une étude des micro-activités de représentation de l'environnement concurrentiel et d'organisation de la veille", Systèmes d'Information et Management, Vol. 13, n4, p. 83-107.

Burton Swanson E., Ramiller N.C. (2004), "Innovating Mindfully with Information Technology", MIS Quarterly, Vol. 28, nº4, p. 553-583.

Calori R. (1988), “Designing a business scanning system”, Long Range Planning, Vol. 22, $\mathrm{n}^{\circ} 1$, p. 69-82.

Caron-Fasan M.-L., Lesca H. (2012), "Projets de mise en place d'une veille anticipative : cas de six organismes du secteur public français", Systèmes d'Information et Management, Vol. $17, \mathrm{n}^{\circ} 2$, p. $81-114$.

Carton-Bourgeois S., De Vaujany F.X., Romeyer C. (2003), "Le modèle de la vision organisante : un essai d'instrumentation”, Systèmes d'Information et Management, Vol. 8, n4, p. 3-29.

Choo C.W. (1999), "The Art of Scanning the Environment”, Bulletin of American Society of Information Science Technology, Vol. 25, n³, p. 21-24. 
Choo C.W. (2001), "Environmental scanning as information seeking and organizational learning", Information Research, Vol. 7, nº1, p. 1-14.

Chung W. (2014), "BizPro: Extracting and categorizing business intelligence factors from textual news articles", International Journal of Information Management, Vol. 34, n², p. 272-284.

Connor R., Dovers S. (2004), Institutional change for sustainable development, Edward Elgar, Cheltenham, UK.

Cooper R.B., Zmud R.W. (1990), "Information technology implementation research: A technological diffusion approach”, Management Science, Vol. 36, n², p. 123-139.

Creswell J.W. (2003), Research Design: Qualitative, Quantitative, and Mixed Methods Approaches, Sage Publications, Thousand Oaks.

Creswell J.W., Clark V.L.P. (2007), Designing and Conducting Mixed Methods Research, Sage Publications, Thousand Oaks.

Di Maggio P.J., Powell W.W. (1983), “The iron cage revisited: Institutional Isomorphism and collective rationality in organizational fields", American Sociological Review, Vol. 48, n², p. 147-160.

Diffenbach J. (1983), “Corporate Environmental Analysis in Large US Corporations", Long Range Planning, Vol. 16, n³, p. 107-116.

Doherty N.F., King M. (2001), "An investigation of the factors affecting the successful treatment of organizational issues in systems development projects", European Journal of Information Systems, Vol. 10, ${ }^{\circ} 4$, p. 147-160.

El Sawy O.A. (1985), "Personal information systems for strategic scanning in turbulent environments: can CEO go on line?", MIS Quarterly, Vol. 9, nº1, p. 53-60.

Englewod J.L., Lenz R.T. (1985), “Whatever Happened to Environmental Analysis?”, Long Range Planning, Vol. 18, n², p. 93-106.

Fabbe-Costes N., Roussat C., Colin J. (2011), "Future sustainable supply chains: what should companies scan?", International Journal of Physical Distribution \& Logistics Management, Vol. 41, n³, p. 228-252.

Fichman R.G. (2001), "The role of aggregation in the measurement of IT related organizational innovation”, MIS Quarterly, Vol. 25, nº4, p. 427-455.

Gilad B., Gilad T. (1988), The business intelligence system: a new tool for competitive advantage, American Management Association, New York.

Giunipero L.C., Hooker R.E., Denslow D. (2012), "Purchasing and supply management sustainability: drivers and barriers", Journal of Purchasing \& Supply Management, Vol. 18, no 4 , p. $258-269$.

Ghoshal S., Westney D.E. (1991), “Organizing Competitor Analysis Systems", Strategic Management Journal, Vol. 12, n¹, p. 17-31.

Hambrick D.C. (1981), "Specialization of environmental scanning activities among upper level executives”, Journal of Management Studies, Vol. 18, n³, p. 299-320.

Hambrick D.C. (1982), "Environmental scanning and organizational strategy", Strategic Management Journal, Vol. 3, n², p. 159-174. 
Hameed M.A., Counsell S., Swift, S. (2012), "A conceptual model for the process of it innovation adoption in organizations", Journal of Engineering and Technology Management, Vol. 29, n³, p. 358-390.

Haveman H.A. (1993), "Follow the Leader: Mimetic Isomorphism and Entry Into New Markets", Administrative Science Quarterly, Vol. 38, nº4, p. 593-627.

Hofer A.R., Hofer C., Eroglu C., Waller M.A. (2011), "An institutional theoretic perspective on forces driving adoption of lean production globally: China vis-à-vis the USA", International Journal of Logistics Management, Vol. 22, nº2, p. 148-178.

Jennings D.F., Lumpkin J. (1992), "Insights between environmental scanning activities and porter's generic strategies: an empirical analysis", Journal of Management, Vol. 18, nº, p. 791-803.

Jennings P.D., Zandbergen P.A. (1995), "Ecologically Sustainable Organizations: An Institutional Approach”, Academy of Management Review, Vol. 20, nº4, p. 1015-1052.

Jepperson R.L., (1991), "Institutions, institutional effects, and institutionalism" in Powell W.W., Di Maggio P.J. (eds.), The new institutionalism in organizational analysis, University of Chicago Press, Chicago, USA, p. 143-163.

Klonglan G.E., Coward E.W.Jr. (1970), "The concept of symbolic adoption: a suggested interpretation", Rural Sociology, Vol. 35, p. 77-83.

Kwon T.H., Zmud R.W. (1987), "Unifying the Fragmented Models of Information Systems implementation" in Boland R.J., Hirschheim R.A. (eds.), Critical Issues in Information Systems Research, John Wiley and Sons Ltd., Chichester, p. 227-251

Lai K.H., Wong C.W.Y., Cheng T.C. (2006), "Institutional isomorphism and the adoption of information technology for supply chain management", Computers in Industry, Vol. 57, $\mathrm{n}^{\circ} 1$, p. 93-98.

Lang J., Calatone R., Gudmundson D. (1997), "Small Firm Information Seeking as a Response to Environmental Threats and Opportunities", Journal of Small Business Management, Vol. 35, $\mathrm{n}^{\mathrm{o}} 1$, p. 11-23.

Lesca N., Caron-Fasan M.-L. (2005), "La veille vue comme un système cybernétique", Finance Contrôle Stratégie, Vol. 8, n 4, p. 93-120

Lesca N., Caron-Fasan M.-L. (2008), "Facteurs d'échec et d'abandon de projets de veille stratégique : retours d'expérience", Systèmes d'Information et Management, Vol. 13, n³, p. $17-42$.

Lesca H., Lesca E., Lesca N., Caron-Fasan M.L. (2010), Gestion de l'information : qualité de l'information et performances de l'entreprise, Litec, Paris.

Lesca N., Caron-Fasan M.-L., Falcy S. (2012), "How managers interpret scanning information", Information \& Management, Vol. 49, n², p. 126-134.

Mayer J. H., Steinecke N., Quick R., Weitzel T. (2012), "More applicable environmental scanning systems leveraging "modern » information systems", Information Systems and EBusiness Management, Vol. 11, nº4, p. 507-540.

Meyer J.W., Rowan B. (1991), "Institutionalized organizations: Formal structure as myth and ceremony", in Powell W.W., Di Maggio, P.J. (eds.), The new institutionalism in organizational analysis, University of Chicago Press, Chicago, USA, p. 41-62. 
Mizruchi M.S., Fein L.C. (1999), "The Social Construction of Organizational Knowledge: A Study of the Uses of Coercive, Mimetic, and Normative Isomorphism", Administrative Science Quarterly, Vol. 44, n4, p. 653-683.

Mosley Roche E. (1996), "Multinational corporations - the emerging research agenda", Journal of Strategic Information Systems, Vol. 5, n²2, p. 129-147.

Nunnally J.C., Barstein I.H. (1994), Psychometric theory, McGraw-Hill, New York.

Oliver C. (1992), “The antecedents of deinstitutionalization”, Organization Studies, Vol. 13, $\mathrm{n}^{\circ} 4$, p. 563-588.

Pagell M., Wu Z. (2009), "Building a more complete theory of sustainable supply chain management using case studies of 10 exemplars", Journal of Supply Chain Management, Vol. $45, \mathrm{n}^{\circ} 2$, p. $37-56$.

Pfeffer J., Salancik G. (1978), The external control of organizations: A resource dependence perspective, Harper \& Row, New York.

Prescott J.E. (1999), “The evolution of competitive intelligence, designing a process for action”, Proposal Management, Vol. 2, n², p. 32-57.

Rai A., Brown P., Tang X. (2009), "Organizational assimilation of electronic procurement innovations", Journal of Management Information Systems, Vol. 26, nº1, p. 257-296.

Raymond L., Julien P.A., Ramangalahy C. (2001), "Technological scanning by small Canadian manufacturers", Journal of Small Business Management, Vol. 39, n², p. 123-138.

Reix R., Fallery B., Kalika M., Rowe F. (2011), Systèmes d'information et management des organisations, Vuibert, Paris.

Robson M.J., Katsikeas C.S., Bello D.C. (2008), "Drivers and Performance Outcomes of Trust in International Strategic Alliances: The Role of Organizational Complexity", Organization Science, 2008, Vol. 19, nº 4, p. 647-665.

Rogers E.M. (1983), Diffusion of Innovations, The Free Press, New York.

Rouibah K., Ould-Ali S. (2002), "Puzzle: a concept and prototype for linking business intelligence to business strategy", Journal of Strategic Information Systems, Vol. 11, n², p. 133-152.

Rust R.T., Cooil B. (1994) "Reliability measures for qualitative data: theory and implications", Journal of Marketing Research, Vol. 31, nº1, p. 1-14.

Sapp S.G., Korsching P.F. (2004), "The Social Fabric and Innovation Diffusion: Symbolic Adoption of Food Irradiation", Rural Sociology, Vol. 69, n³, p. 347-369.

Scott W.R. (1995), Institutions and Organizations: Foundations for Organizational Science, Sage Publications, California.

Slack T., Hinings B. (1994), "Institutional Pressures and Isomorphic Change: An Empirical Test”, Organization Studies, Vol. 15, nº, p. 803-827.

Smircich L., Stubbart C. (1985), "Strategic management in an enacted world", Academy of management review, Vol. 10, no 4, p. 724-736.

Stubbart C.I. (1982), “Are environmental scanning units effective?”, Long Range Planning, Vol. 15, n³, p. 139-145.

Schuman M.C. (1995), "Managing legitimacy: Strategic and institutional approaches", Academy of Management Review, Vol. 20, n³, p. 571-610. 
Thong, J.Y.L. (1999), "An integrated model of information systems adoption in small businesses", Journal of Management Information Systems, Vol. 15, nº 4, p. 187-214.

Venkatesh V., Brown S.A., Bala H. (2013), "Bridging the qualitative-quantitative divide: guidelines for conducting mixed methods research in information systems", MIS Quarterly, Vol. 37, $\mathrm{n}^{\mathrm{o}} 1$, p. 21-54.

Veugelers M., Bury J., Viaene S. (2010), "Linking technology intelligence to open innovation", Technological Forecasting \& Social Change, Vol. 77, n², p. 335-343.

Verra, L.G., Karoui, M. \& Dudezert, A. (2012), “Adoption symbolique d'un Réseau Social pour entreprise : Le cas de Bouygues Construction", 17ème colloque de l'AIM, Bordeaux, France.

Walker H., di Sisto L., McBain D. (2008), "Drivers and barriers to environmental supply chain management practices: Lessons from the public and private sectors", Journal of Purchasing \& Supply Management, Vol. 14, nº1, p. 69-85

Walkers B., Jiang J., Klein G. (2003), "Strategic information and strategic decision making: the EIS/CEO interface in smaller manufacturing companies", Information \& Management, Vol. 40, n6, p. 487-495.

Wei C.-P., Lee Y.-H. (2004), "Event detection from online news documents for supporting environmental scanning”, Decision Support Systems, Vol. 36, nº4, p. 385-401.

Williams Z., Lueg J.E., Taylor R.D., Cook R.L. (2009), "Why all the changes?: An institutional theory approach to exploring the drivers of supply chain security (SCS)", International Journal of Physical Distribution \& Logistics Management, Vol. 39, nº 7, p. 595618.

Xu X., Kaye G., Duan Y. (2003), 'UK executives' vision on business environment for information scanning: A cross industry study", Information \& Management, Vol. 40, n5, p. 381-389.

Yasai-Ardekani M., Nystrom P.C. (1996), "Designs for Environmental Scanning Systems: Tests of a Contingency Theory", Management Science, Vol. 42, n², p. 187-204.

Yoon J. (2012), "Detecting weak signals for long term business opportunities using text mining of web news", Expert System with Application, Vol. 39, nº16, p. 12543-12550.

Zhang Y., Dang Y., Chen H., Thurmond M., Larson C. (2009), "Automatic online news monitoring and classification for syndromic surveillance", Decision Support Systems, Vol. 47, n'4, p. 508-517.

Zhou Z., Cheng S., Hua B. (2000), "Supply chain optimization of continuous process industries with sustainability considerations", Computers \& Chemical Engineering, Vol. 24 n $^{\circ}$ 2-7, p. 1151-1158.

Zhu K., Kraemer K.L., Xu S. (2006), "The process of innovation assimilation by firms in different countries: A technology diffusion perspective on e-business", Management Science, Vol. 52, nº10, p. 1557-1576.

\section{Appendixes}


Appendix A: Studies describing IS adoption process

\begin{tabular}{|c|c|c|c|c|c|c|c|c|c|}
\hline Author & \multicolumn{3}{|c|}{ Pre-adoption } & \multicolumn{4}{|c|}{ Adoption } & \multicolumn{2}{|c|}{ Post-adoption } \\
\hline $\begin{array}{l}\text { Klonglan \& } \\
\text { Coward } \\
(1970)\end{array}$ & $\begin{array}{l}\text { Awareness. An } \\
\text { individual might } \\
\text { become aware of } \\
\text { the introduction of } \\
\text { an innovation. }\end{array}$ & $\begin{array}{l}\text { Information. } \\
\text { Individual may } \\
\text { actively seek out } \\
\text { information about } \\
\text { the innovation. }\end{array}$ & $\begin{array}{l}\text { Evaluation. } \\
\text { Individual may } \\
\text { decide that the } \\
\text { innovation is } \\
\text { suited to his/her } \\
\text { needs. }\end{array}$ & \multicolumn{2}{|c|}{$\begin{array}{l}\text { Trial. The potential adopter may seek for a } \\
\text { demonstration of the innovation. If the it } \\
\text { meets or exceeds adopter expectations, } \\
\text { he/she may decide to adopt it (use } \\
\text { adoption) }\end{array}$} & & & & \\
\hline $\begin{array}{l}\text { Rogers } \\
(1983)\end{array}$ & \multicolumn{2}{|c|}{$\begin{array}{l}\text { Knowledge. Exposure to the innovation } \\
\text { and an understanding of how it functions. }\end{array}$} & $\begin{array}{l}\text { Persuasion. An } \\
\text { attitude is formed } \\
\text { toward the } \\
\text { innovation. }\end{array}$ & \multicolumn{2}{|c|}{$\begin{array}{l}\text { Decision. An individual engages in } \\
\text { activities that result in a decision to either } \\
\text { adopt or reject the innovation. }\end{array}$} & \multicolumn{2}{|c|}{$\begin{array}{l}\text { Implementation. The innovation is actually } \\
\text { put to use }\end{array}$} & \multicolumn{2}{|c|}{$\begin{array}{l}\text { Confirmation. Individuals seek reinforcement } \\
\text { for the decision made, but may reverse this } \\
\text { decision if exposed to conflicting messages. }\end{array}$} \\
\hline $\begin{array}{l}\text { Kwon \& } \\
\text { Zmud } \\
(1987) ; \\
\text { Cooper \& } \\
\text { Zmud } \\
(1990)\end{array}$ & \multicolumn{3}{|c|}{$\begin{array}{l}\text { Initiation. Companies justify the need for adopting an IT. } \\
\text { They perform an active and/or passive scanning of } \\
\text { organizational problems/opportunities and IT solutions are } \\
\text { undertaken. Finally, a match is found between an IT solution } \\
\text { and its application in the organization. }\end{array}$} & \multicolumn{2}{|c|}{$\begin{array}{l}\text { Adoption. A decision is reached to invest } \\
\text { resources necessary to accommodate the } \\
\text { implementation effort. }\end{array}$} & $\begin{array}{l}\text { Adaptation. The IT } \\
\text { application is } \\
\text { developed, installed, } \\
\text { and maintained. }\end{array}$ & $\begin{array}{l}\text { Acceptance. } \\
\text { Organizational } \\
\text { members are induced } \\
\text { to commit to IT } \\
\text { application usage. }\end{array}$ & $\begin{array}{l}\text { Routinization. Usage } \\
\text { of the IT application } \\
\text { is encouraged as a } \\
\text { normal activity }\end{array}$ & $\begin{array}{l}\text { Infusion. Increased } \\
\text { organizational } \\
\text { effectiveness is } \\
\text { obtained by using the } \\
\text { IT }\end{array}$ \\
\hline $\begin{array}{l}\text { Fichman, } \\
\text { (2001); Rai, } \\
\text { Brown } \text { et } \\
\text { al., (2009) }\end{array}$ & $\begin{array}{l}\text { Awareness. Key } \\
\text { decision makers } \\
\text { are aware of a new } \\
\text { IT. }\end{array}$ & \multicolumn{2}{|c|}{$\begin{array}{l}\text { Interest. The firm is committed to } \\
\text { actively learn more about the IT. }\end{array}$} & $\begin{array}{l}\text { Evaluation. } \\
\text { Acquiring specific } \\
\text { innovation-related } \\
\text { products and } \\
\text { initiating } \\
\text { evaluation or trial. }\end{array}$ & $\begin{array}{l}\text { Commitment. The } \\
\text { firm has committed to } \\
\text { use of the IT in a } \\
\text { significant way for } \\
\text { one or more } \\
\text { activities. }\end{array}$ & $\begin{array}{l}\text { Limited } \\
\text { deployment. } \\
\text { Establishing a } \\
\text { program of regular, } \\
\text { but limited, use of } \\
\text { the IT for some } \\
\text { activities. }\end{array}$ & $\begin{array}{l}\text { Partial deployment. } \\
\text { Establishing a } \\
\text { program of regular, } \\
\text { but limited, use of } \\
\text { the IT. }\end{array}$ & \multicolumn{2}{|c|}{$\begin{array}{l}\text { General deployment. The firm has reached a } \\
\text { state where the IT is used on a substantial } \\
\text { fraction of activities. }\end{array}$} \\
\hline $\begin{array}{l}\text { Burton } \\
\text { Swanson \& } \\
\text { Ramiller } \\
(2004)\end{array}$ & \multicolumn{3}{|c|}{$\begin{array}{l}\text { Comprehension. Through the sense making efforts of its } \\
\text { members, the firm learns more about an IT innovation and } \\
\text { develops an attitude or stance toward it and positions itself, in } \\
\text { a basic way, as a prospective adopter or non-adopter. }\end{array}$} & \multicolumn{2}{|c|}{$\begin{array}{l}\text { Adoption. The firm develops a supportive } \\
\text { rationale, or business case about the IT } \\
\text { innovation. Organization decides whether } \\
\text { to proceed and commit its resources. }\end{array}$} & \multicolumn{2}{|c|}{$\begin{array}{l}\text { Implementation. Bringing the innovation to } \\
\text { productive life for its users. }\end{array}$} & \multicolumn{2}{|c|}{$\begin{array}{l}\text { Assimilation. It commences as the IT } \\
\text { innovation begins to be absorbed into the } \\
\text { worklife of the firm and to demonstrate its } \\
\text { usefulness. In time, the innovation may come } \\
\text { to be infused and routinized. }\end{array}$} \\
\hline $\begin{array}{l}\text { Zhu, } \\
\text { Kraemer et } \\
\text { al., (2006) }\end{array}$ & \multicolumn{3}{|c|}{$\begin{array}{l}\text { Initiation. Evaluating the potential benefits of IT to improve a } \\
\text { firm's performance in value chain activities such as cost } \\
\text { reduction, market expansion, and supply chain coordination. }\end{array}$} & \multicolumn{4}{|c|}{$\begin{array}{l}\text { Adoption. Making the decision to use IT for value chain activities (i.e., allocating } \\
\text { resources and physically acquiring the technology) }\end{array}$} & \multicolumn{2}{|c|}{$\begin{array}{l}\text { Routinization. The stage in which IT is widely } \\
\text { used as an integral part in a firm's value chain } \\
\text { activities. }\end{array}$} \\
\hline $\begin{array}{l}\text { Hameed, } \\
\text { Counsell et } \\
\text { al., (2012) }\end{array}$ & \multicolumn{3}{|c|}{$\begin{array}{l}\text { Initiation. It consists of activities related to recognizing a } \\
\text { need, acquiring knowledge or awareness, forming an attitude } \\
\text { towards the innovation and proposing innovation for } \\
\text { adoption. }\end{array}$} & \multicolumn{2}{|c|}{$\begin{array}{l}\text { Adoption-decision. It reflects the decision } \\
\text { to accept the idea and evaluates the options } \\
\text { for its acquisition and implementation. }\end{array}$} & \multicolumn{4}{|c|}{$\begin{array}{l}\text { Implementation. It involves acquisition of innovation, preparing the organization for use of } \\
\text { the innovation, performing a trial for confirmation of innovation, acceptance of the } \\
\text { innovation by users and continued actual use of the innovation. }\end{array}$} \\
\hline
\end{tabular}




\section{Appendix B: Activity sector of organizations interviewed during the two research}

phases

\begin{tabular}{|c|c|c|c|c|}
\hline \multirow[t]{2}{*}{ Activity sectors } & \multicolumn{2}{|c|}{ Qualitative phase } & \multicolumn{2}{|c|}{ Quantitative phase } \\
\hline & $\mathbf{N b}$ & $\%$ & $\mathbf{N b}$ & $\%$ \\
\hline Public administration & 5 & 11.9 & 5 & 4 \\
\hline Building .................. & 1 & 2.4 & 2 & 1.6 \\
\hline Chemistry and plastic & - & - & 3 & 2.4 \\
\hline Trade & 1 & 2.4 & 15 & 11.9 \\
\hline Automotive, aviation, rail, naval manufacturer & - & - & 4 & 3.2 \\
\hline Electronics and computing & 5 & 11.9 & 3 & 2.4 \\
\hline Energy & - & - & 1 & 0.7 \\
\hline Transportation / logistics infrastructure management & 3 & 7.1 & 3 & 2.4 \\
\hline Food industry & 7 & 16.7 & 8 & 6.3 \\
\hline Mechanical and metallurgy... & 1 & 2.4 & 6 & 4.8 \\
\hline Health and beauty & 1 & 2.4 & 3 & 2.4 \\
\hline Transport and/or delivery of service & 12 & 28.6 & 55 & 43.6 \\
\hline Other & 6 & 14.3 & 18 & 14.3 \\
\hline Total & 42 & 100 & 126 & 100 \\
\hline
\end{tabular}

\section{Appendix C: Questionnaire}

In my company/organization, we perform S.Scan applied to the SSC because:

1. We are convinced that we must perform S.Scan for the SSC

2. Performing S.Scan applied to SSC helps us implicate our collaborators in our SSC strategy

3. We want to keep informed of ongoing developments

4. By communicating on S.Scan applied to SSC we avoid being made a bad example of

5. Other companies / organizations in our sector perform S.Scan applied to SSC

6. We wait to see what others do before we launch ourselves into S.Scan applied to SSC

7. We are looking to identify opportunities

8. We are looking to identify threats

9. We seek to anticipate changes that could affect us in order to be prepared

10. We seek to maintain our competitive position

11. We want to feed our innovation process

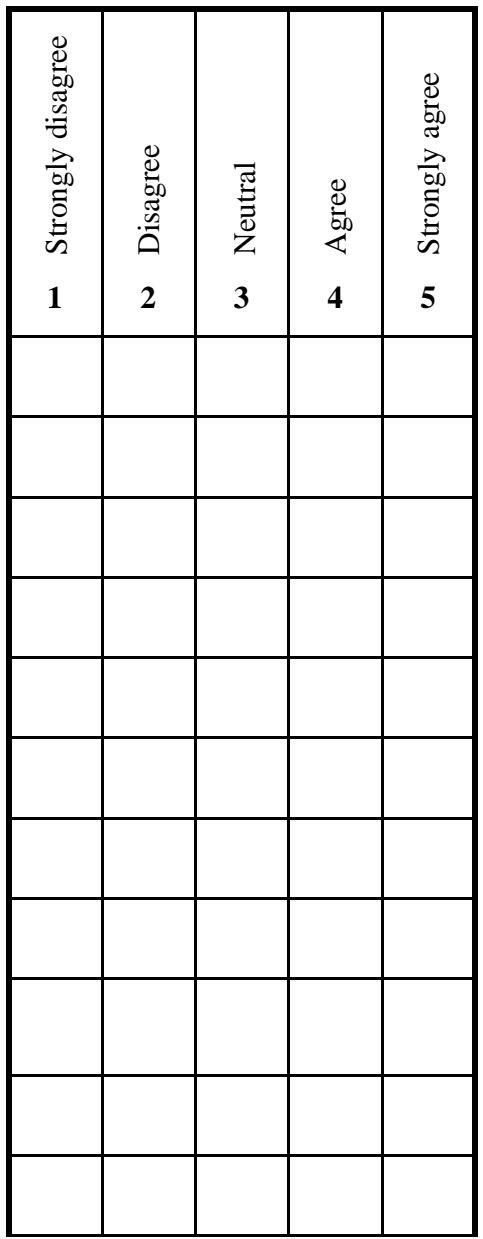


12. We wish to develop new markets / new activities

Specify the difficulties that your company/organization has encountered in performing S.Scan applied to SD:

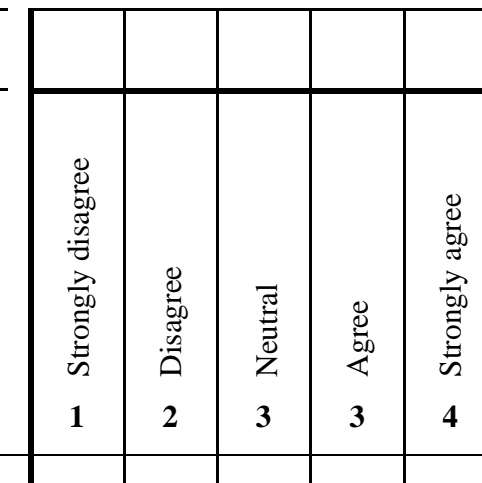

1. We struggle to define what SSC is

2. We have difficulty in organizing the process of S.Scan applied to the SSC

3. We lack the impetus needed to perform S.Scan applied to the SSC

4. The information does not flow well

5. The culture of our organization does not lend itself well to S.Scan applied to the SSC

6. The leadership of our organization does not sufficiently support the effort of S.Scan applied to the SSC

7. We do not have access to the information that we need to perform S.Scan applied to the SSC

8. Internally, we lack tools or technical solutions to perform S.Scan applied to the SSC

9. We have not found outside providers who offer tools or satisfactory methods to help us perform S.Scan applied to the SSC

10. We do not know how to assess the ROI of S.Scan applied to the SSC

11. The cost of entry to perform S.Scan applied to the SSC is deterrent

12. We do not have the time to perform S.Scan applied to the SSC

13. S.Scan applied to the SSC is not consistent with the strategy of our organization

14. We lack know-how to perform S.Scan applied to the SSC

15. We do not have the personnel needed to perform S.Scan applied to the SSC

16. Doing S.Scan applied to the SSC is much more complicated than we thought

17. Our organization has not defined its expectations well concerning S.Scan applied to the SSC

18. We have difficulty identifying what needs to be monitored

19. S.Scan applied to SSC is not part of the priorities of our organization 